\title{
د. حاتم الصكر والموقف النقدي من قصيدة النثر العربية
}

د. داسم حسين سلطان الخالاي

\section{كلية التربية / جامعة واسط}

الملخص

وقف النقاد العرب مواقف منباينة من قصيدة النثر ، منقسمين على أنفسهم ، فمنهم من وقف بالضد

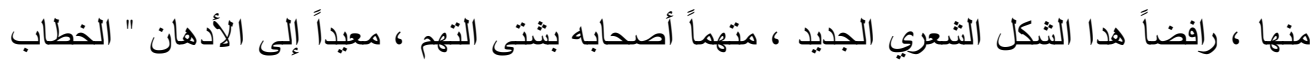

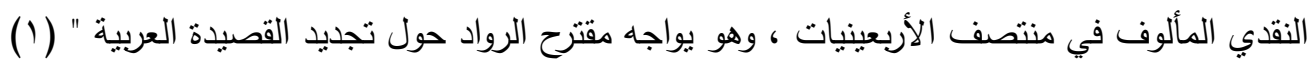
؛ إد بقي التطير من التجديد مسيطراً عليه قبل أن تسطع شمسه في سموات القصيدة العربية ـ ولسنا هنا بصدد دراسة ذلك الموقف والاسباب الكامنة وراءه ، فقد شغل مساحة غير قليلة من الخطاب النقدي حول قصبدة النثر ؛ لكن الذي يهمنا - هنا - هو الموقف المؤيد لقصيدة النثر والمرحب بها ؛ إذ شغل مساحة واسعة من اشتغالات النقاد العرب ، وقد كرس بعضهم جزءاً كبيراً من جهده النقدي

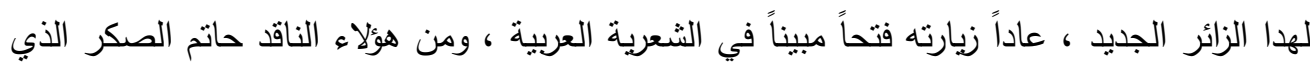
كرس جزءاً غير قليل من مشروعه النقدي إلى قصبدة النثز ، كاشفاً الخصائص الفنية والجمالية التي هري تتضمن هذا النوع الثعري ، فضلاً عن اشكالية المصطلح ومشروعيته ، وما إلى ذلك من قضايا نقدية شغلت المشهد النقدي الراهن ؛إذ بنى موقفه النقدي من قصبدة النثر عبر مجموعة من الدراسات التي توزعت بين كتبه ، سواء أكانت في ضمن كتاب أم شغلت الكتاب كله ، كما تجسد في كتابيه " قصيدة النثر في اليمن " و" حلم الفراشة " ، كما من المفيد القول : إن بعض هذه الدراسات اشتغلت على الجانب التتظيري ، في حين جمعت دراسات أخرى التنظير والإجراء معاً، وهو ما نقف عنده في متن هذه الدراسة. 


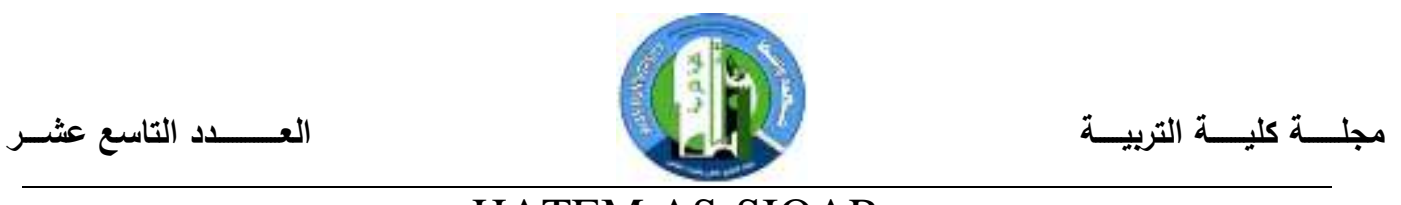

HATEM AS-SIQAR

And The Critical Attitude Of Prose Poem

Arab critics took different positions of the prose poem, Some of them are against it, refusing to accept this new poetic form, accusing those who write it of various charges, Recalling critical discourse fashionable forties of $20^{\text {th }}$ century when facing the pioneers of free poem.

What concerns us here is the pro-prose poem position, As filling large areas of the writings of Arab critics, they considered it as a noting groundbreaking in Arabic poetics. AS-SIQAR is one of those.

He has built his position of prose poem in a series of studies which spread in his books as in (Prose Poem in Yaman) and (The Butterfly Dream). 
وقف النقاد العرب مواقف منباينة من قصيدة النثر ، منقسمين على أنفسهم ، فمنهم من وقف بالضد

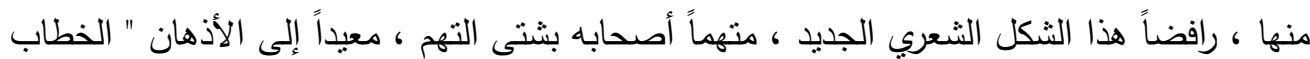
النقدي المألوف في منتصف الأربعينيات ، وهو يواجه مقترح الرواد حول تجديد القصيدة العربية " (1) ؛ إد بقي التطير من التجديد مسيطراً عليه قبل أن تسطع شمسه في سموات القصيدة العربية ـ ولسنا هنا بصدد دراسة ذلك الموقف والاسباب الكامنة وراءه ، فقد شغل مساحة غير قليلة من الخطاب النقدي حول قصيدة النثر ؛ لكن الذي يهمنا - هنا - هو الموقف المؤيد لقصيدة النثر والمرحب بها ؛ إذ شغل مساحة واسعة من اشتغالات النقاد العرب ، وقد كرس بعضهم جزءاً كبيراً من جهده النقدي هوة هن

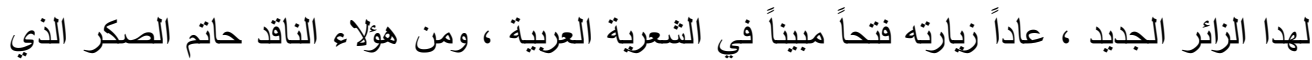
كرس جزءاً غير قليل من مشروعه النقدي إلى قصيدة النثر ، كاشفاً الخصائص الفنية والجمالية التي هوني تتضمن هذا النوع الشعري ، فضلاً عن اشكالية المصطلح ومشروعيته، وما إلى ذلك من قضايا نقدية شغلت المشهد النقدي الراهن ؛إذ بنى موقفه النقدي من قصيدة النثر عبر مجموعة من الدراسات التي توزعت بين كتبه ، سواء أكانت في ضمن كتاب أم شغلت الكتاب كله ، كما تجسد في كتابيه " قصيدة النثر في اليمن " و" حلم الفراثة " ، كما من المفيد القول : إن بعض هذه الدراسات اشتغلت على الجانب التظيري ، في حين دراسات أخرى جمعت بين التنظير والإجراء ، وهو ما نقف عنده في منت هذه الدراسة.

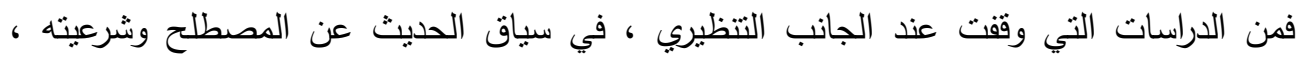
دراسته " قصيدة النتر والاحتمالات المؤجلة " التي نأني أهميتها من أنها تعترف سلفاً بأن " قصبدة النثر موضوع مؤجل في جدول أعمال التحديث والتجديد الثعريين ، وأن تظلَّ احتمالاً قائماً قابـاً للتأجيل يرضى الأطراف الشعرية كلها وهي تتعايش وتتحاور وتتقاطع بدءاً من العمود حتى القصيدة

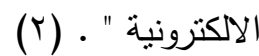

وبعد أن يمرَ على التجارب التجديدية التي سبقت قصيدة النثر يقرر الصكر : أن الريحاني من أكثر المؤثرين في التمهيد لقصيدة النثر العراقية ، وإنْ لم تكن بمعزلٍ عمّا كان بحدثُ في العراق ؛ كُّن ولاسيما تجربة الزهاوي في كتابة الثعر المرسل ، وروفائيل بطي في كتابة الثعر المنثور، وحسين مردان في كتابة النثز المركز (ب) ؛ غير أنّ تلك التجارب المذكورة لم تغيّر من حقيقة أن التجديد 
سار على غير المألوف ، فبعد أقل من نصف قرن على محاولات وتقليد النماذج الثعرية القديمة

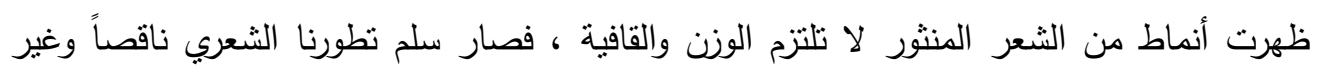

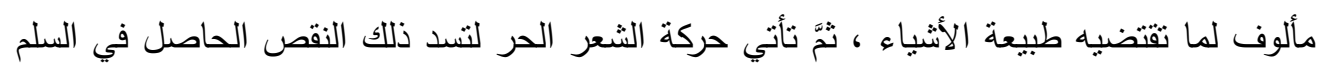

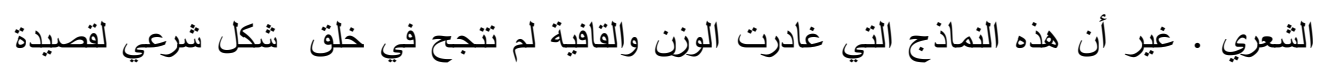

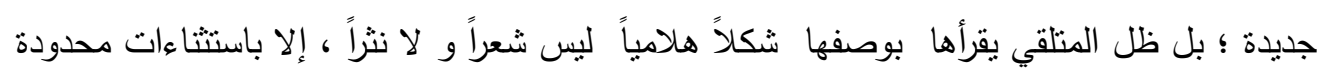

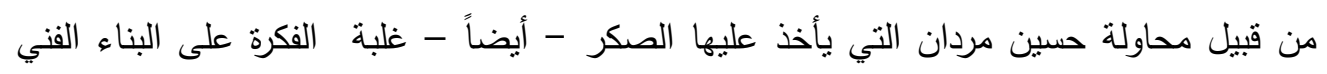

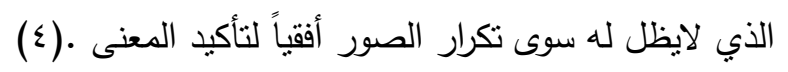

أما بشأن العوامل التي كانت وراء ظهورها - والكلام للصكر - فلا ينكر مؤسسوها دوافعهم

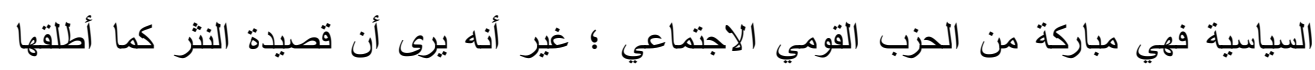

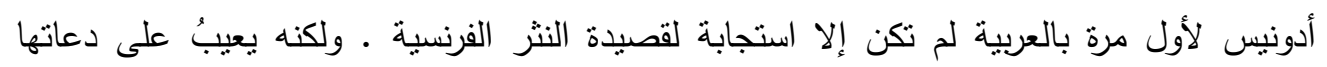

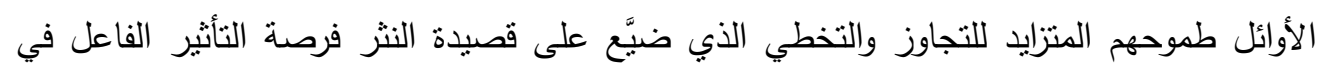

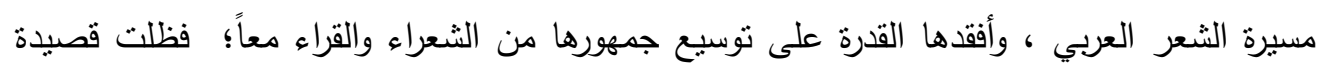

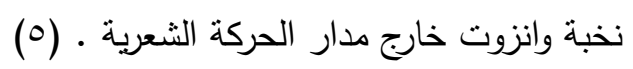

ويضع الصكر يده على الإثكال الذي وسم العلاقة بين قصيدة النثر ومتلقيها؛ إذ يرجع بعض ذلك الكاء

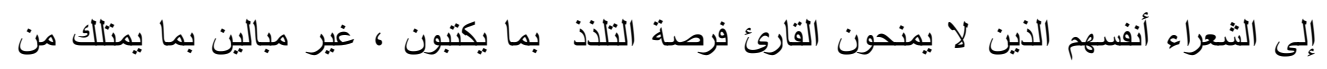

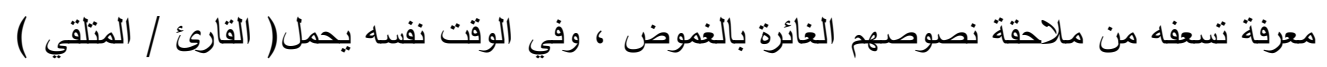

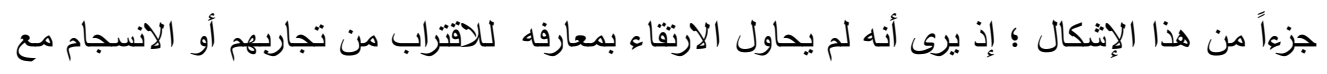

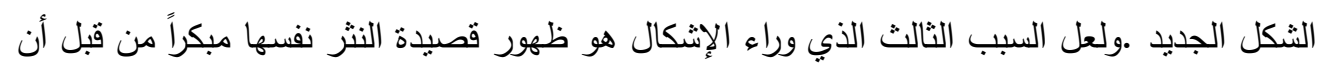

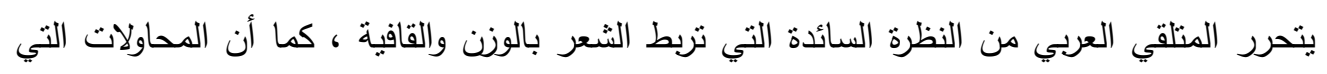

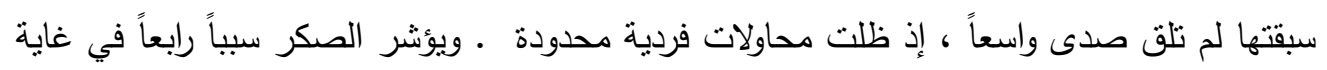

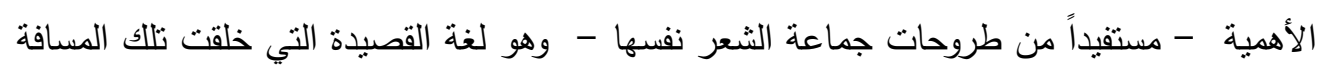

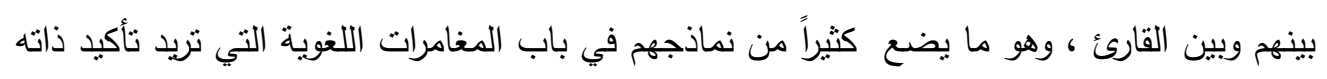

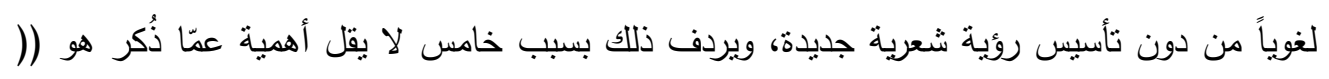

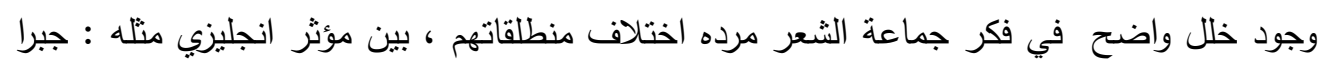

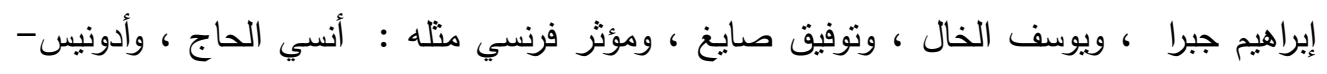


إلى حد ما - وعصام محفوظ ـ وهذ ما جعل عقد الجماعة ينفرط سريعاً ، على الرغم من عودة

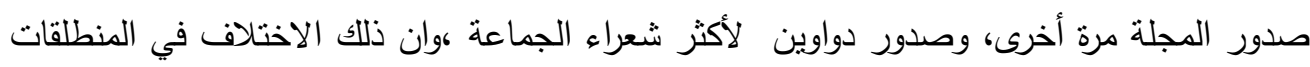
هو الذي جعل شاعراً مثل "جبرا إبراهيم جبرا" الذي بمثل محاولة الموازنة بين أصالة المفردة العربية

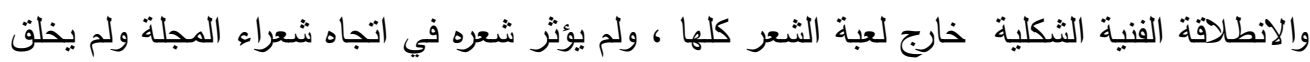
بدوره اتجاهاً ..

والحقيقة أن (جبرا) لم يكن مخلصا كل الإخلاص لقصيدة النثر؛ إذ كان موزعاً بين الكتابة

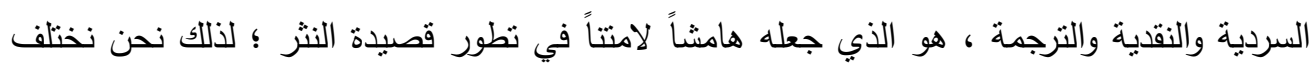

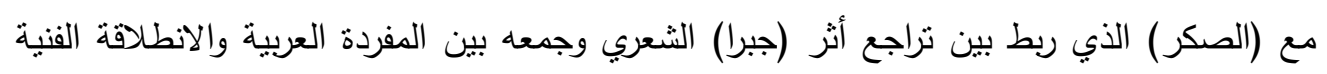

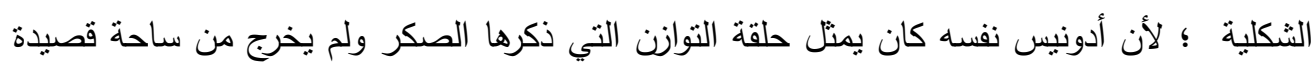

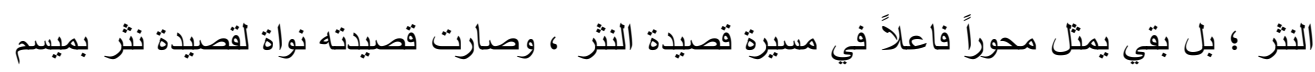
• عربي

أما بصدد قصيدة النثر العراقية فإنه برى أن الموقف النقدي بإزائها انقسم على ثلاثة مواقف

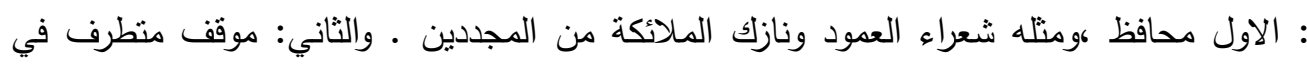

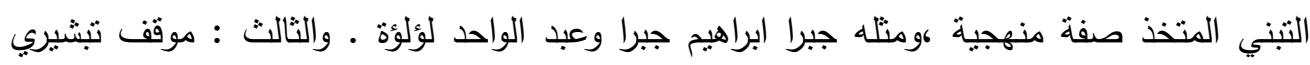

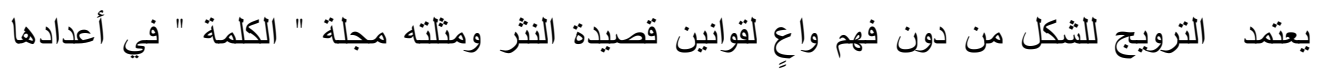

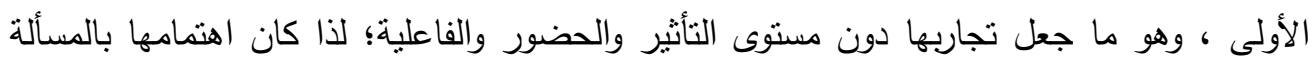

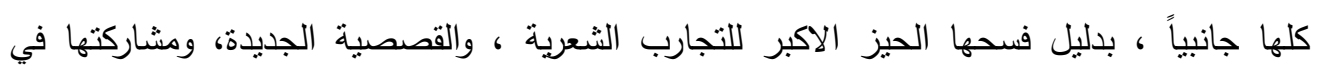

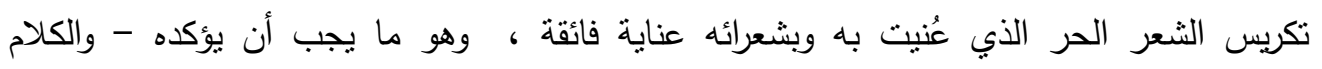

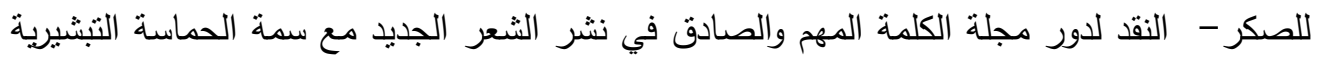

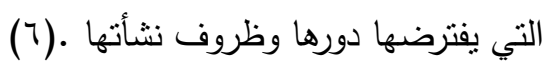

وبعد أن يستعرض تجارب عدد من شعراء مجلة ( الكلمة )،يخلص الناقد إلى تقويم تجربة

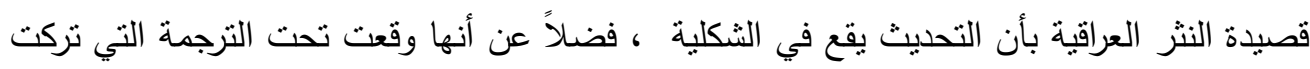

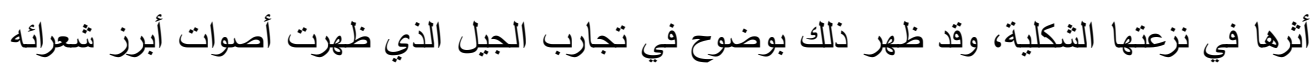

في السبعينيات. (v) 


\section{مجلـــة كليـــة التربيــة}

ومن الدراسات التي تدور في فلك التنظر ما جاء في كتابه ( في غيبوبة الذكرى ) ، الذب تضمن

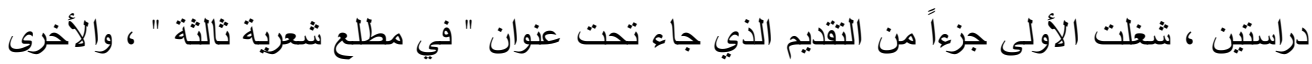

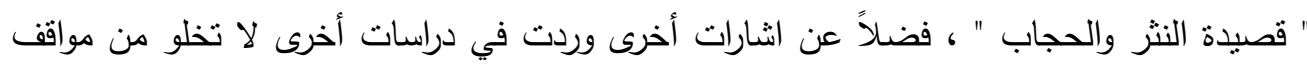
واضحة من هذا النوع الثعري .

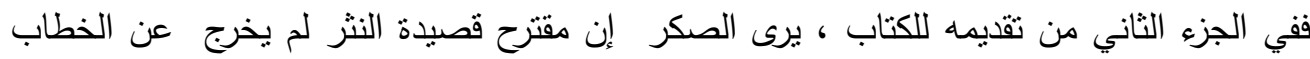

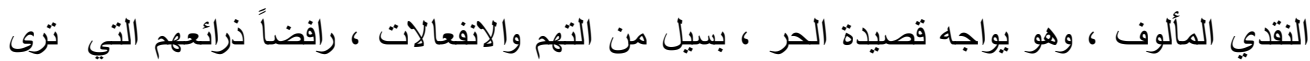

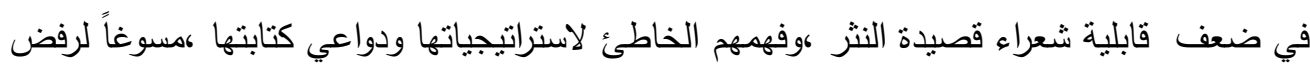

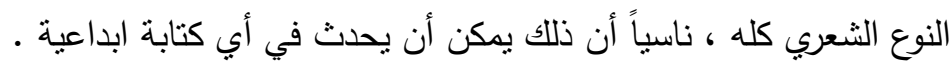

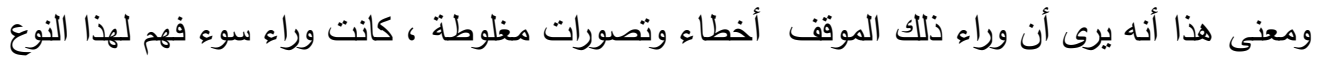

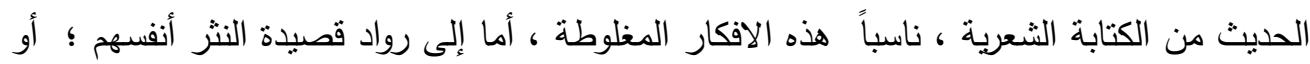

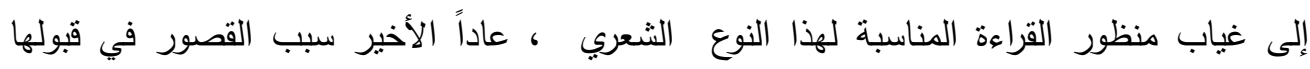
وتحديد هويتها وشرعيتها .

ينطلق الصكر - في رأيه هذا- من رؤيته النقدية في قراءة النص الأدبي ، أعني نظرية القراءة

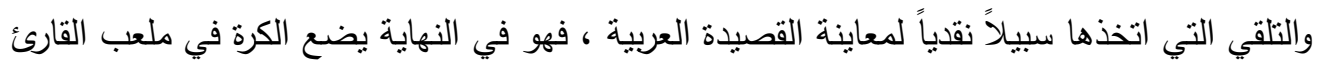

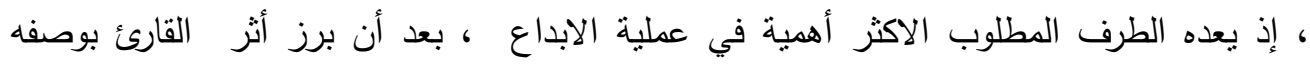

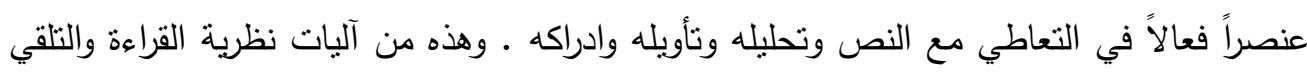

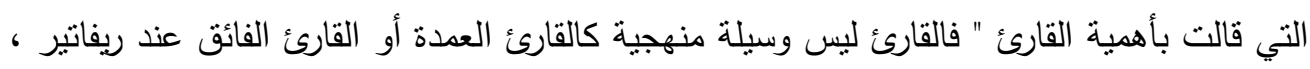

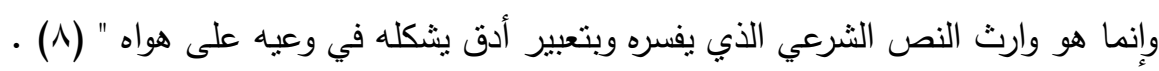

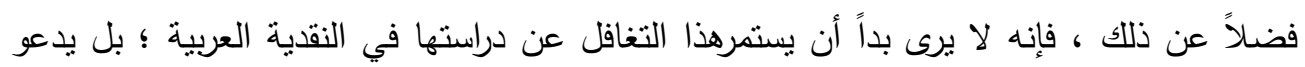

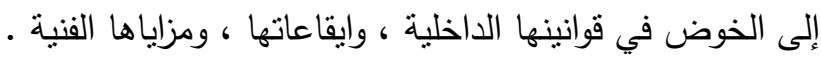

مشيراً إلى جهود بعض النقاد الذين استتطقوا نصوصها في محاولة لتتميط نماذجها ، ومقاربتها نصياً

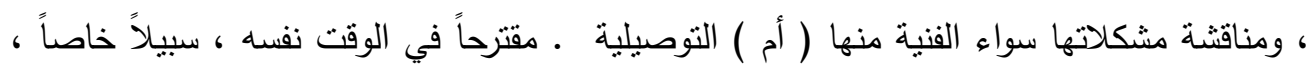

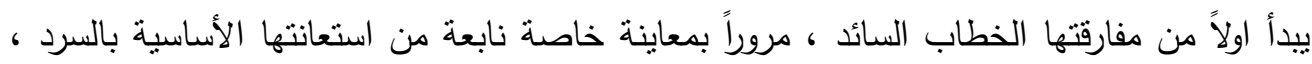


وتأثثث القصيدة بعناصر على مستوى ضمائر السرد ، والدلالة ، والبناء ، والإيقاع ، والمستوى

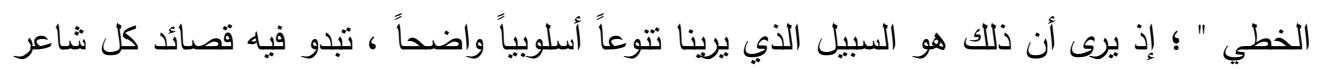

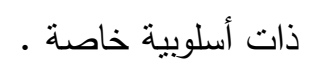

كما أنه بعتقد من الضرورة الخروج عن النموذج الجبراني والكتابات الصوفية ؛ لأن ذلك يوقع اللبس

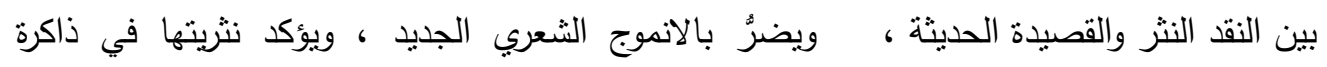

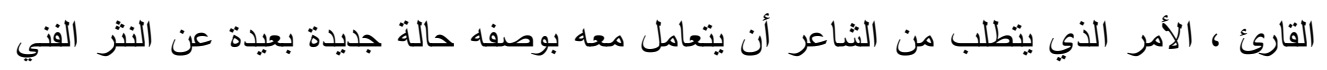

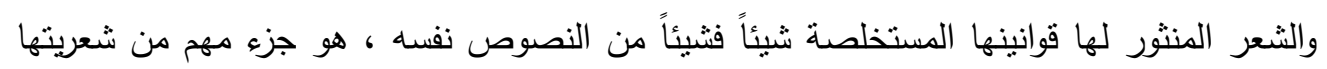

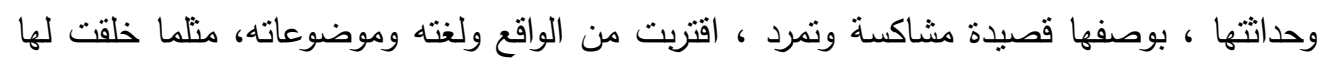

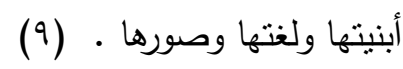

من ذلك كله نخلص إلى أن مهمة قصبدة النثر ليست سهلة ؛ بل هي عسيرة ، وأن عسرها منأت من " تتاقض فوضاها ونظامها ، النثر والثعر ، رفض القاعدة وترسيخ القانون ، استبدال المعاني الجزئية

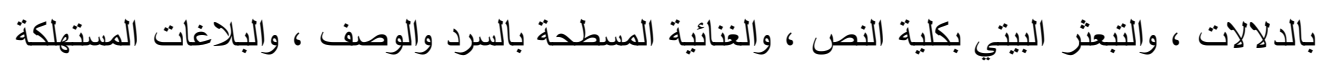

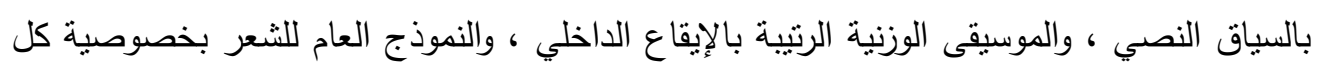

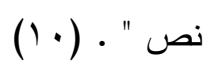

وهذه الأمر كلها عناصر فارقة بين قصيدة النثر والأثكال الثعرية السابقة ، الأمر الذي يغدو فيه

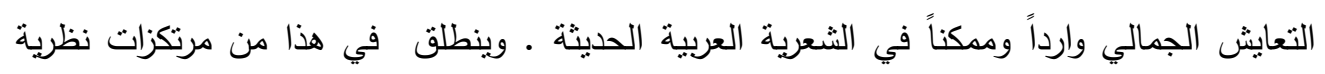

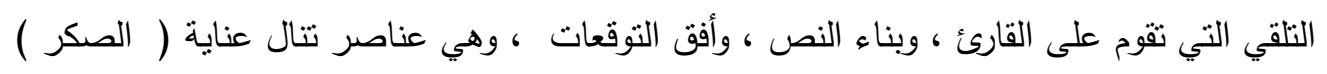
في قراءة النصوص الحديثة ـ (11)

أما الدراسة الأخرى فهي " قصيدة النثر وحجاب التلقي " التي حاول فيها الصكر أن يضع إصبعه

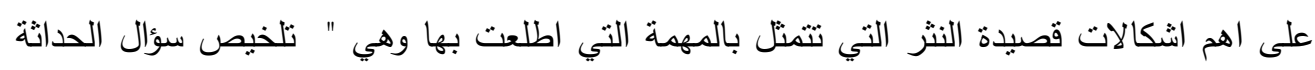

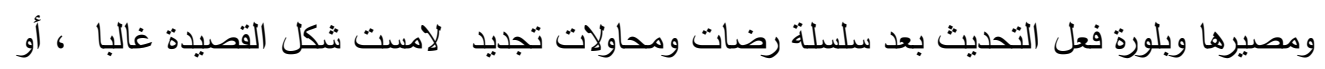

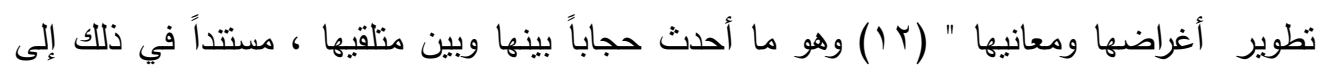

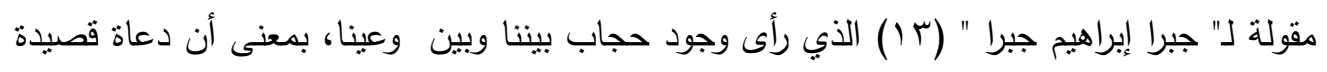

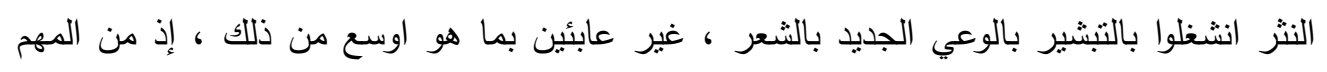




\section{مجلـــة كليـــة التربيــة}

وجود وعي شامل داخل المتلقي وجهازه القرائي • بمعنى أن غياب ذلك الوعي ألف حجاباً بين قصيدة

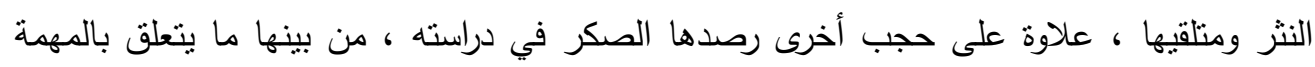

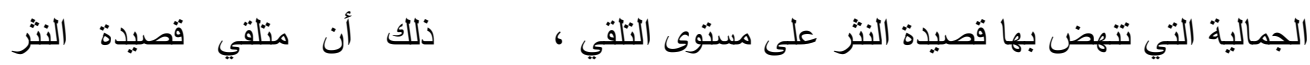

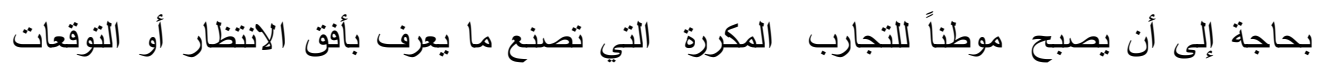

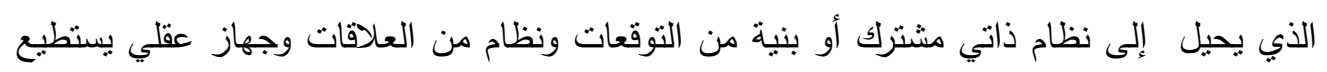

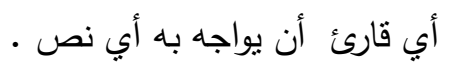

وهذا هو أس الاشكالية التي تعاني منها قصيدة النثر ؛ إذ يحتكم القارئ إلى ما استقر في

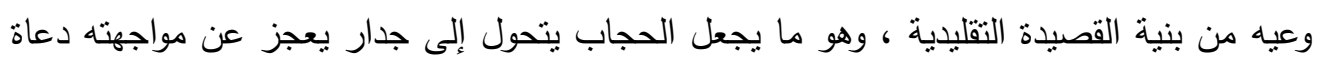

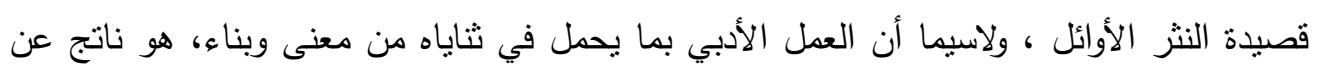

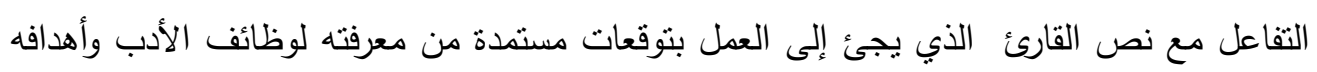

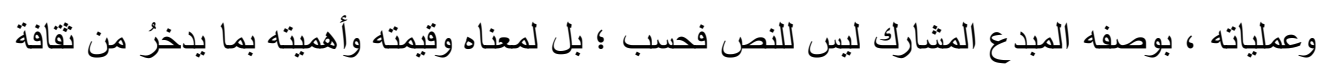

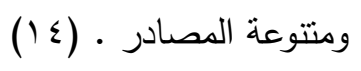

ومن جهة أخرى ، يرى الصكر أن ثمة أسباب وراء ضعف تلقي قصيدة النثر منها ما هو ذاتي ينعلق

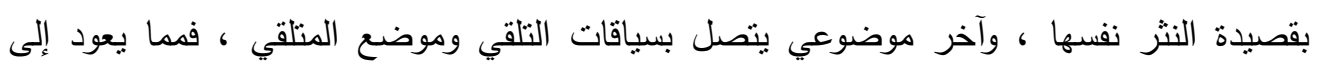

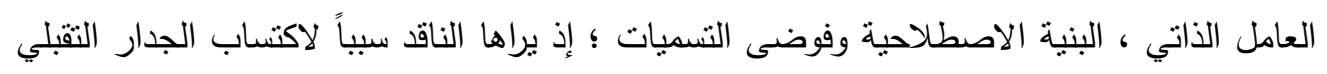

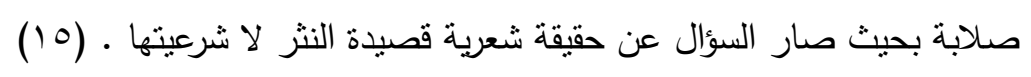

مما ينطوي تحت جناح العامل الذاني ، وكان سبياً في خلخلة التلقي ، هو تقنية قصيدة النثر ، التي

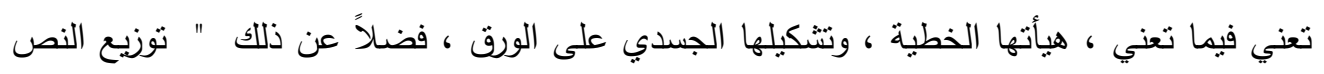

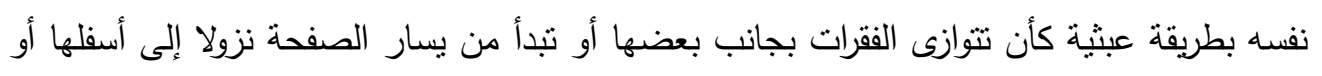

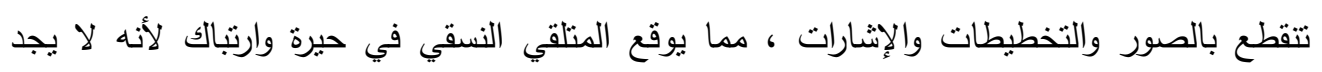

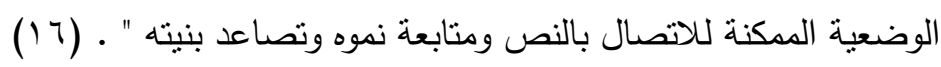




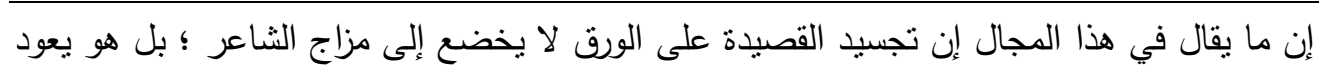

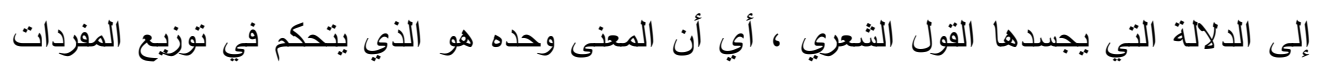

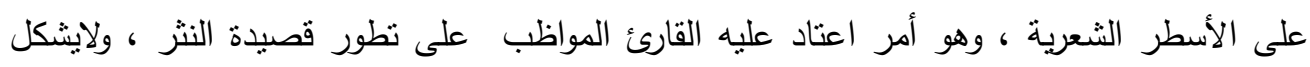

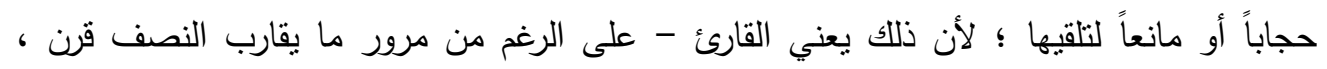

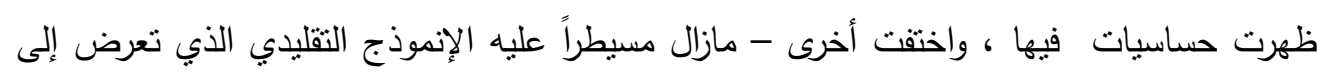

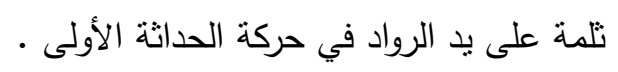

ومن الحجب الأخرى التي وقف عندها الناقد ، لغة قصيدة النثر القائمة على المغايرة للانساق

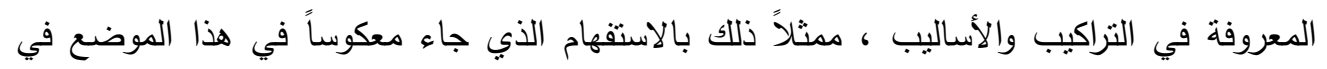

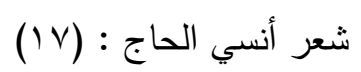
تجيئين كيف لا أبالي إذ أصبحت الجملة ثلاثية التركيب أسلوبياً : خبرية تيئين استقهامية مبتورة بسبب نأخير الأداة منفية لا أبالي فيما يريد الثاعر الاستفهام والنفي اللاحق فقط .

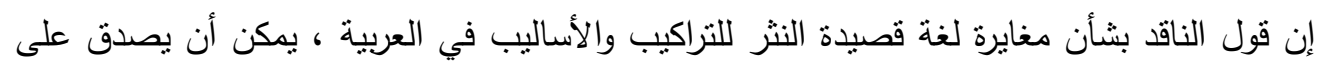

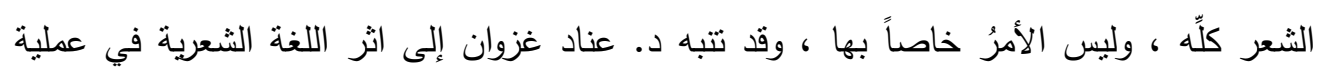

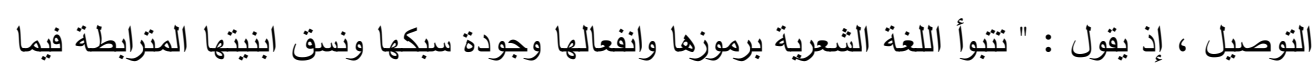

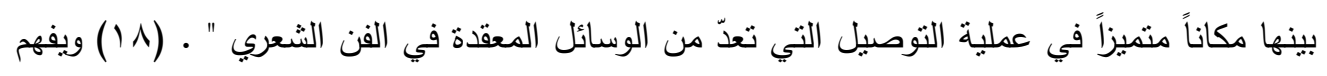

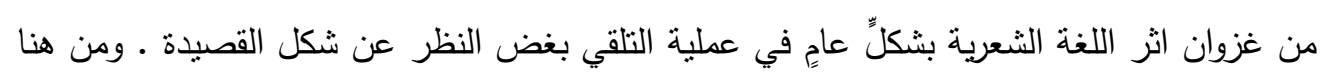


عدّ الأخير" اللقاء بين الثاعر والقارئ تجربة إنسانية تتسم بالسعة والثمول الا وهي تجربة التوصيل

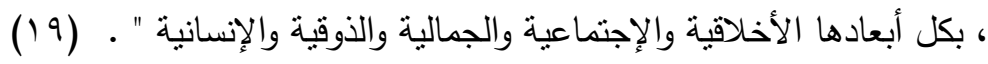

ويعد الناقد إيقاع قصيدة النثر واحداً من مشكلات قصيدة النثر ، وأكثر الششكلات الاتصالية حدة ، ذلك لأنه خيّب أفق إنظظار المتلقي بما تهبه قصيدة النتر في صدم لتوقعاته التي وقفت عندها الناقدة

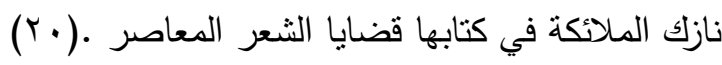

ويختم الناقد حجب التلقي بالغوض والانغلاق اللذين خيما على مجمل قصبدة النثر ، على الرغم

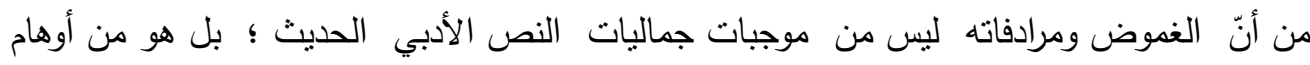

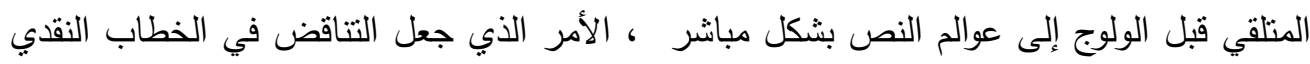

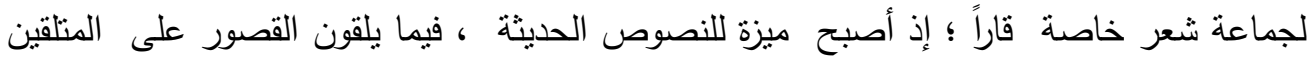

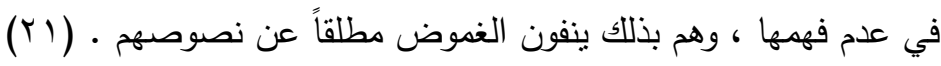

ولاثك في أن الغموض الذي قصده الصكر لا يشمله تشبيه عبد القاهر الجرجاني المدقق في

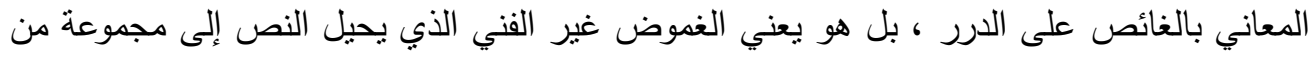

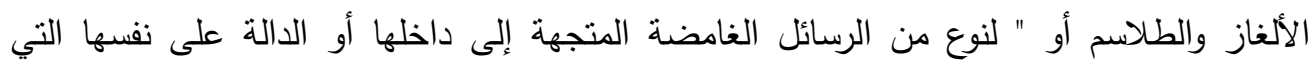

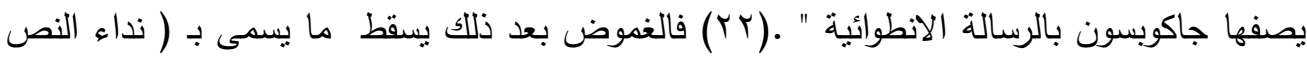

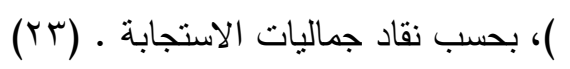

ومن جهة أخرى يأخذ الناقد على دعاة قصيدة النثر تتاقضهم في التعامل مع كثير من قضايا قصيدة

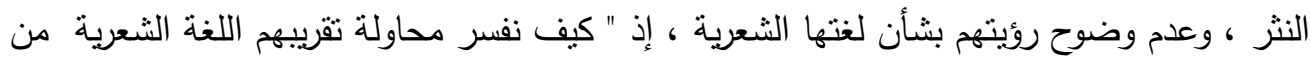

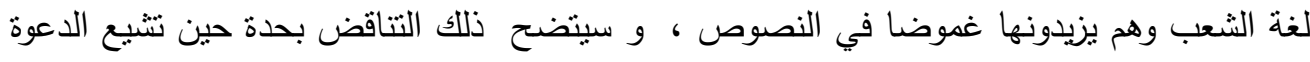

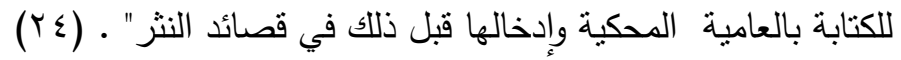


وبلمح الصكر في ذلك إلى الدعوة التي تبناها يوسف الخال في الكتابة في العامية حين " اختار طريقاً

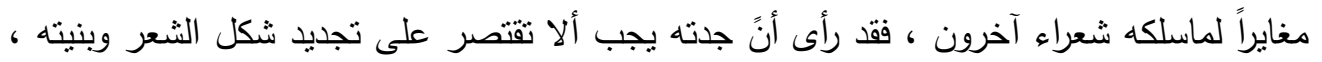

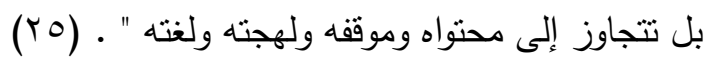

كما يعيب عليهم موقفهم من التراث رفضاً وقبولاً، ومن الغرب الذي سيصبح من ينابيع

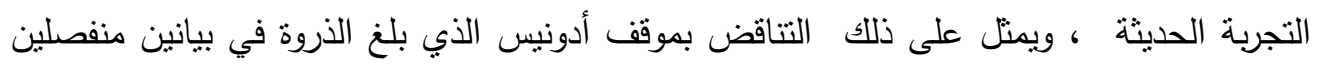

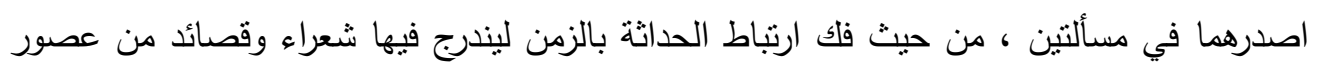

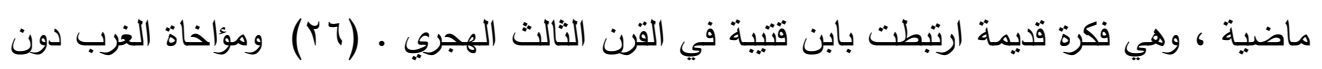

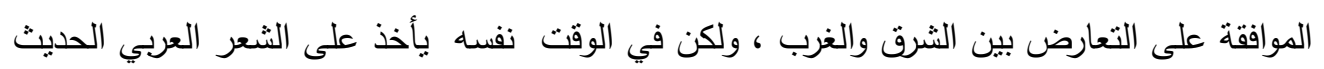

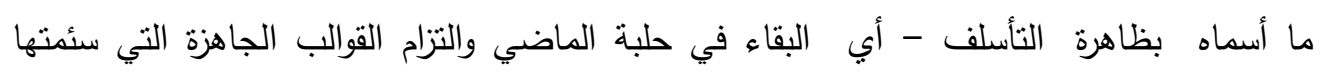

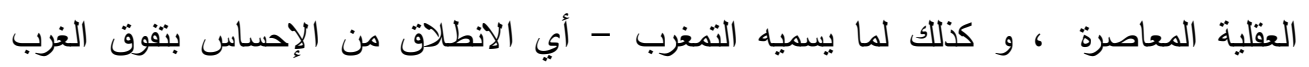

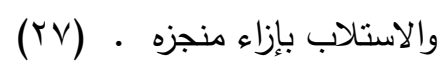

وأخيراً يختم الناقد هذه الدراسة بنتيجة مفادها : " إن خطاب قصيدة النثر سيظل مصطدما بجدار

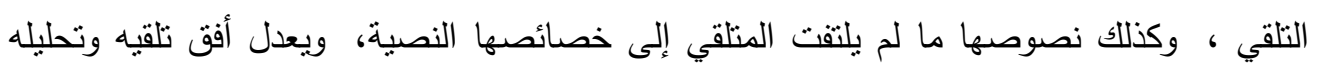

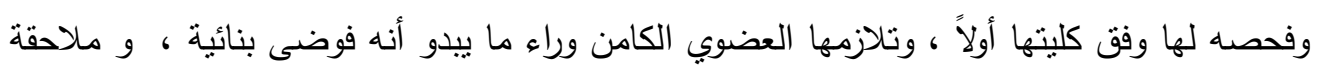

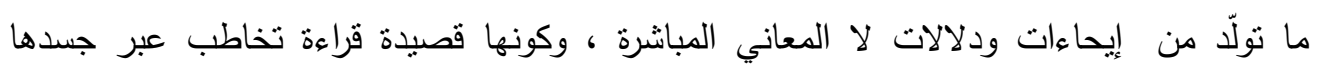

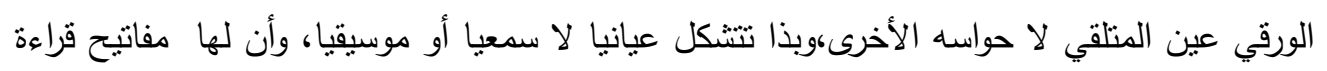

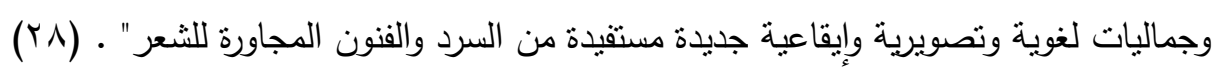

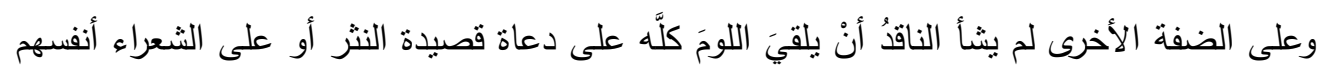

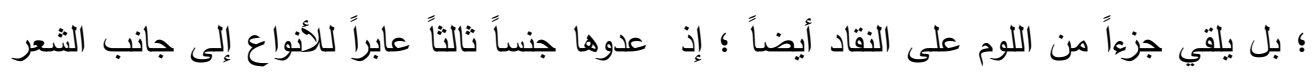

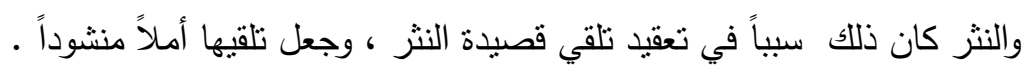

إن قول الصكر قد يصدق على مقولة هذا الناقد ؛ ولكن هناك نقاد أخرون تعاملوا مع قصيدة النثر

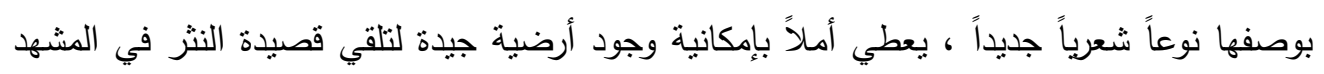


الثقافي • يقول الناقد ياسين النصير " لم يعد الأمر بأنّ لوناً شعرياً قد يولد من تجمع ألوان شعر أخرى

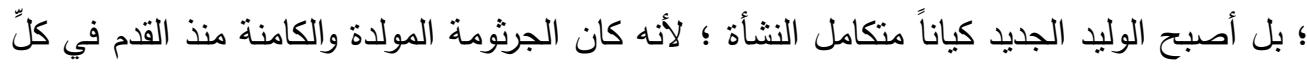

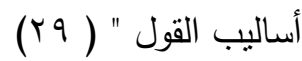

ومن ذلك ينطلق الصكرفي في قراءته لمشروع مجلة شعر بشكل عام ، إذ يرى أنّ ما قامت بـ

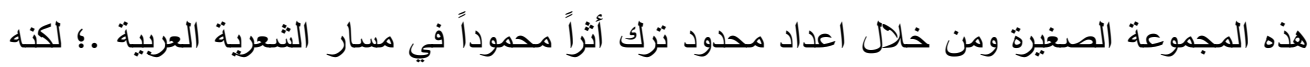
بالمقابل عدّ ما بشّرت به المجلة بحماسة غريبة لأفكار سوزان برنار في أطروحتها عن قصبدة النثر من بودلير حتى أيامنا، من أكثر الجنايات التحديثية فداحة ؛ إذ ليس الخطأ في تبني أفكار برنار

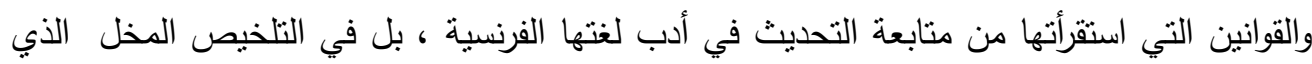
صنعه كثّاب المجلة لتلك الأفكار ، والصنمية التي منحوها لها، على الرغم من أن أصحاب المجلة قد تباينت مرجعياتهم ؛ إذ اهتم كل عدد بتقديم ترجمات مطولة لشاعر غربي حداثوي ، ولم يمنع تباين الحاضنات الفكرية لهم من الالتقاء حول سلالة متمردة، ترضي القادمين من الثقافة الإنكلو سكسونية كجبرا وصايغ والخال، والفرانكفونيين كأدونيس وأنسي الحاج وأبي شقرا ، كما حرصوا على تقديم تردي الثقافة المتتوعة لا الثعرية فحسب ، فظهرت الاهنمامات بالتشكيل والدراما في إثارة لحاجة قارئهم

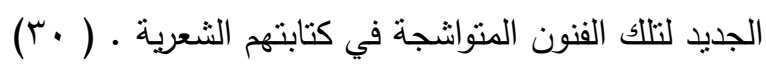

ويحسن بنا أن نختم القول بخاتمة الناقد نفسه - وهو يشير إلى أهمية مشروع (مجلة شعر) في

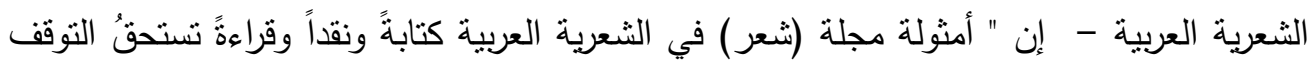
والدراسة بعد مضي خمسين عاماً على الثرارة الأولى التي أثعلتها التوجهات النظرية والنصوص والرؤى التي زخرت بها المجلة ، ( على ال) رغم (من ) سنوات حياتها القصيرة التي استمرت بعد

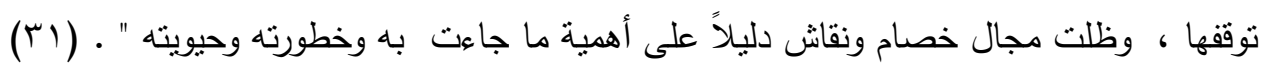
والواقع أنّ مجلة (شعر) لم تكن نتظر إلى قصبدة النثر من منظور نقدي فحسب ؛ بل أرات أن تبشر بنوعٍ شعريٍٍ جديدٍ ، ولم تجد أمامها سوى نموذج سوزان برنار الذي وصلنا عبر كتابها ( قصيدة

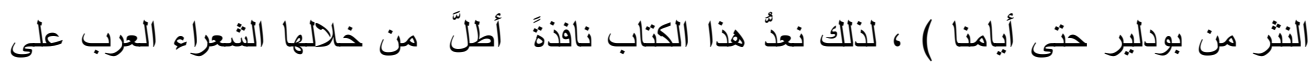
عوالم قصيدة النثر، ومن ثمّ انطلقوا في اصطناع كون خاص لهم ، يمكن أن يؤسس لقصيدة نثر 
لم يتوقف موقف حاتم الصكرمن قصيدة النثز على المستوى التنظيري فحسب ؛ بل أنه من النقاد الذين اندفعوا في عوالم النصوص الإبداعية والوقوف على جمالياتها ومخبوءاتها الفنية والأسلوبية ، فضلاً عن أثزها في المتلقي ، وهو المهر عند الصكر ؛ إذ إنه من النقاد الأوائل الذين انفتحوا على المناهج النقدية الحديثة التي نجحت في تسليط الأضواء على النصوص الإبداعية من خلال رؤية نقدية واضحة المعالم • وهكذا كانت نظريات القراءة والتقبل واجهة الناقد في قراءة النصوص الإبداعية • ومنها قصيدة النثر

ولعل كتابه " قصبدة النثز في اليمن أجيال وأصوات " انطلق من تلك النظرة التي انتظمت كتابات الصكر ، وجعلته في مقدمة النقاد العراقيين والعرب الذين أسسوا لقراءة نقدية محايدة بعيدة عن الرفض • والقبول

تصدر الكتاب تتظير نقدي جاء بعنوان " قصيدة النثر معضلات الكتابة وأسئلة القراءة " ، معترفاً في أولها أن كثثراً من الأحاديث عن قصيدة النثر لاتخرج عن كونها استعادة للاسئلة أكثر من تقديم مقترحات ، أو التعريف بالقبول المطلق أو الرفض التام في مجال الأنواع والأشكال الثعرية ـ مؤكداً

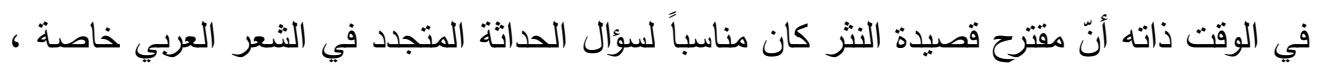
لأنه نجح في إحداث خرق في ذاكرة مكتترة بالقيم الثعرية التقليدية ، والمرصوصة بأغراض ما كان

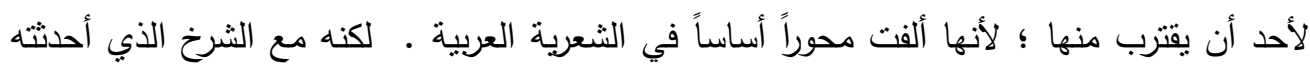
قصيدة النثر في جسد القصيدة العربية ، فإن ما ارتكبه الخطاب النقدي من جنايات نقدية ، جعلت فرصة تلقيها ضعيفة قياساً إلى القصيدة التقليدية ، ولعل من بين الجنايات التي رصدها الصكر ، هي عدم عناية الخطاب النقدي " بالنظرية النقدية قدر عنايته بمفردات تتصل عموماً بالأدب شعراً ونثراً

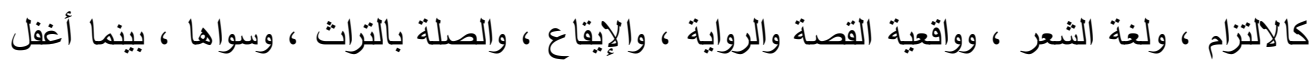

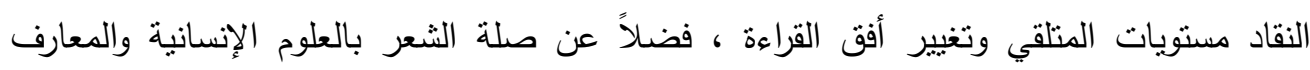
وقنوات التوصيل ، والأثر أو المحرك النفسي • ومما يتصل بتلك الجناية ما أسماه الناقد بالمقايسة النموذجية التي تعني عنده " اصطناع نموذج شكلي أو نوعي (شعر الجواهري مثلاً أو شوقي) ثم الاحتكام إليه لقبول أو رفض النماذج اللاحقة ، وذلك ما سوف تكرسه المدرسة العربية والمناهج الدراسية حتى في مراحل الدراسة الجامعية الأولية والعليا ، وما سادها من شروح مضمونية وتعريفات 
وتحليلات غير نصية ، لا تساهم إلا بتحويل الأدب إلى تاريخ أدبي أو مسلسل محفوظات وتفسيرات

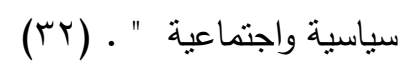

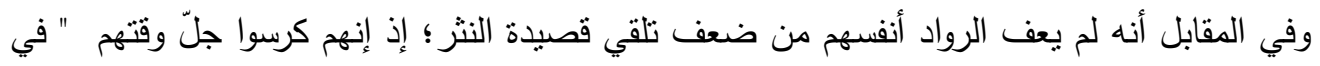

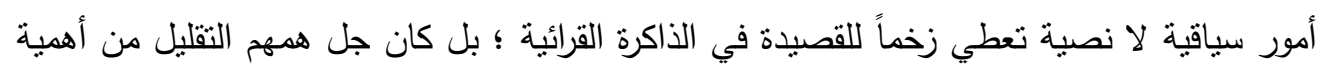

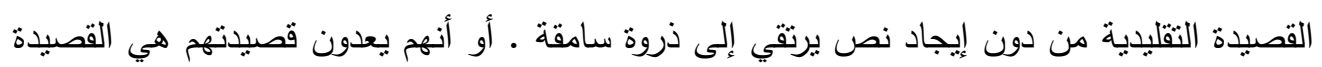

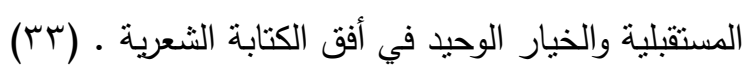

هذه الجنايات التي رصدها الصكر في هذا التقديم ، ولات أفعالاً قوية لدى الرافضين لهذا النوع

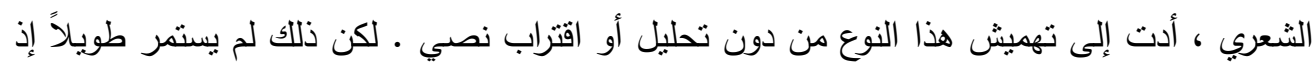

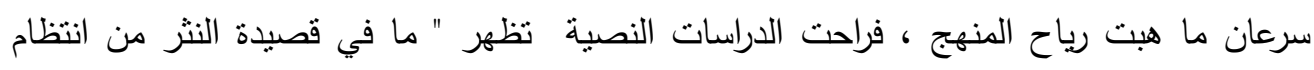

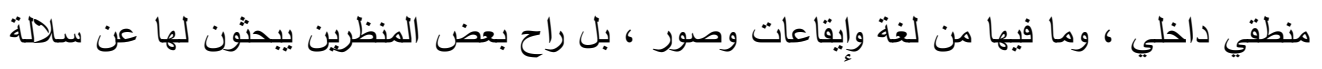

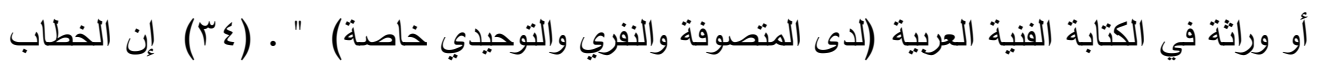

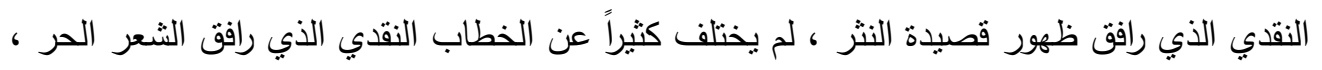

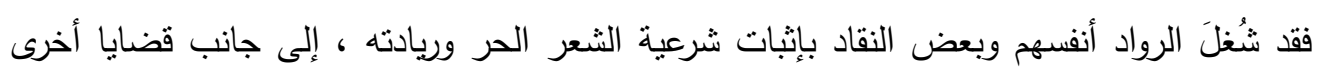
سياقية . (ro)

واضح هنا أن الصكر يكرر كثيراً من الأفكار التي وردت في كتابة السابق " في غييوبة الذكرى " وأن

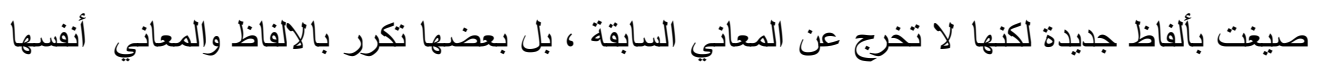
، وهو أمر دأب عليه الصكر في كثير من دراساته .

أما الجانب النتظيري فقد ركز على أجيال قصيدة النثر اليمنية ، ويبدو أن نوجهه إلى هذه القصيدة

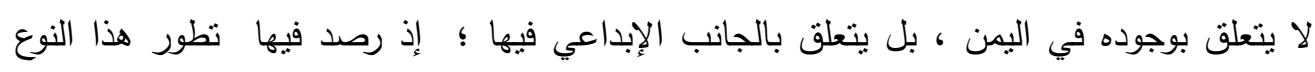

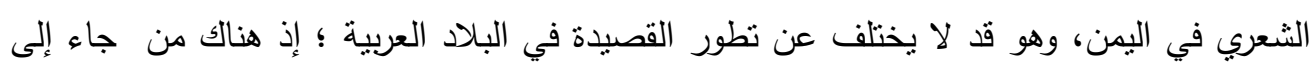

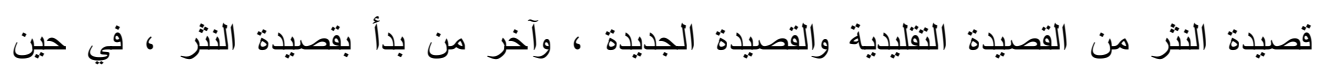

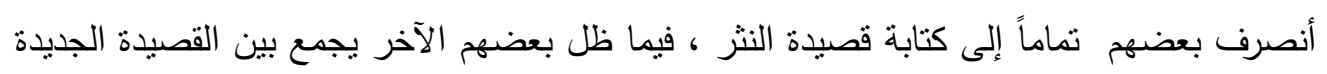

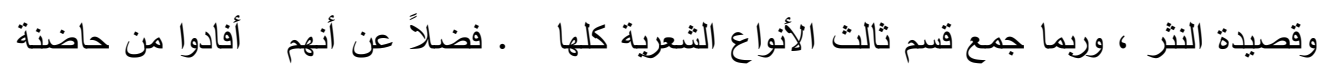

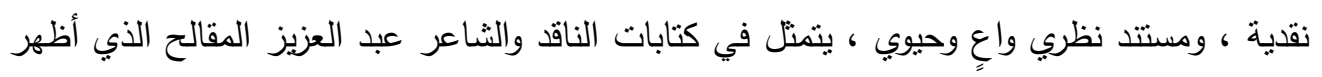


قبولاً مدروساً وحذراً ومشجعاً لتجاربهم ، مطلقاً على القصيدة اسم (القصيدة الأجد) بعد أن زال تحفظه

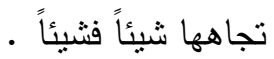

وقد أفصح الصكرعن منهجه النقدي في معاينة تجارب الثعراء اليمنيين الذين جمعهم

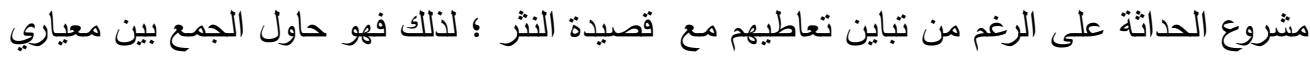

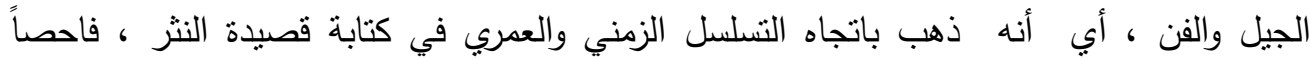

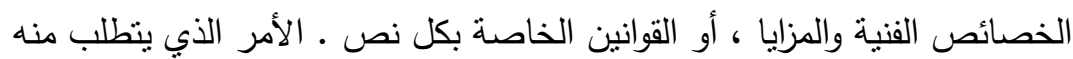

بتقسيم النصوص المتوفرة إلى ثلاث موجات تتتابع متلامسة ومبتعدة ، كما يحدث لموجات البحر ذاته

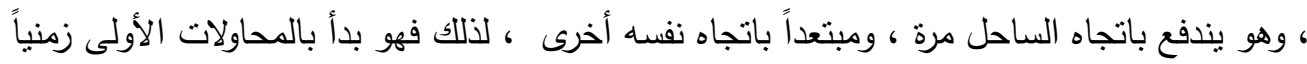

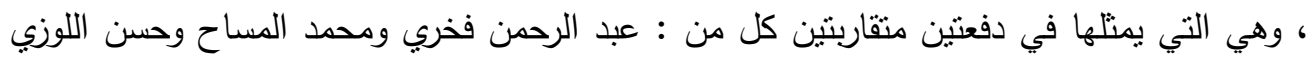
وذو يزن ، ثم عبد الودود سيف وعبد الكريم الرازحي ومحمد حسين هيثم وشوفي شفيق ـ فضلاً عن

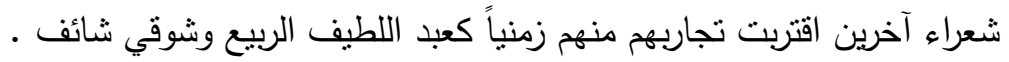

وقد أطلق على الموجة الاولى : نصوص الإرهاص والتأسيس ، فيما وجد في الموجة الثانية التي

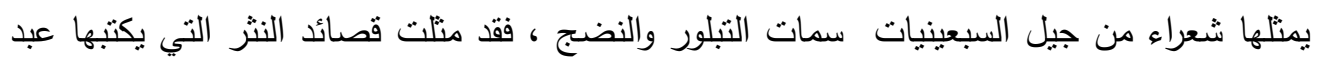
الودود سيف ، وعبد الكريم الرازحي ، وعبد اللطيف الربيع ومحد حسين هيثم وشوقي شفيق وشوقي

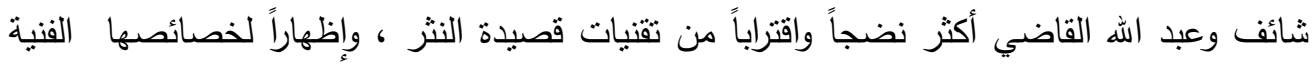

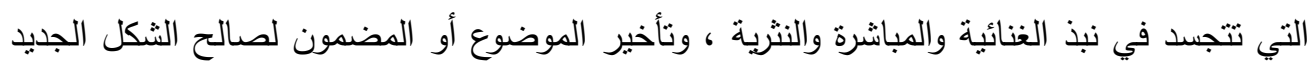

أما الموجة الثالثة فقد اطلق عليها : نصوص المغامرة ، والانعطاف عقائدياً إلى قصيدة

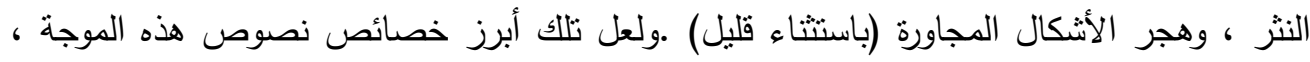

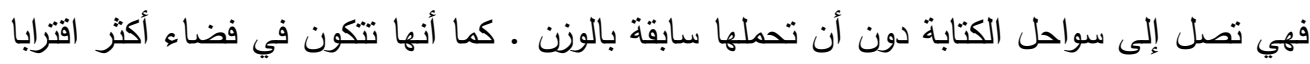

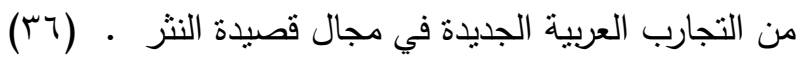
ليصل بعد ذلك إلى القول " إن ديوان (قصيدة النثر) العربي سوف يثرى بجملة من هذه

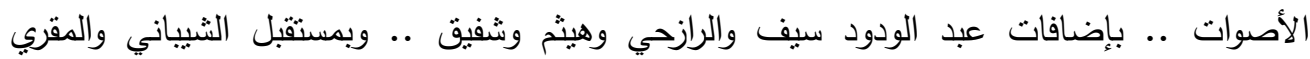


والزراعي والمنصور و وعود سبيع والنجار واللوزي .. ولا أثك في أن النقد الأدبي المتسلح بالمنهجية

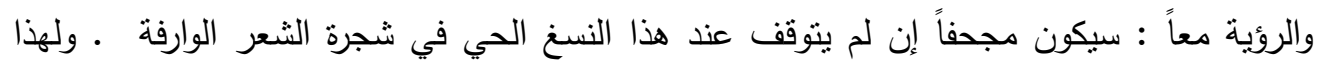
سأجعل الخاتمة مفتوحة لأية إضافة أو تعديل أو تغيير .. ففي الثعر لا ندري من أين يطلع الزلزال ولا كيف يخمد البركان أو تمطر السحب " . . (rv)

ومن الدراسات التي عالجت قصيدة النثر العربية معالجه نقدية على وفق آليات منهجية واضحة المعالم ، دراسة الناقد د. حانم الصكر الموسومة بـ " حلم الفراثة " التي اتخذت من مناهج القراءة والتلقي ميدانا لقراءة قصيدة النثز الحديثة ، فهو لم يدرس الإيقاع بعيداً عن تغير القنوات الاتصالية

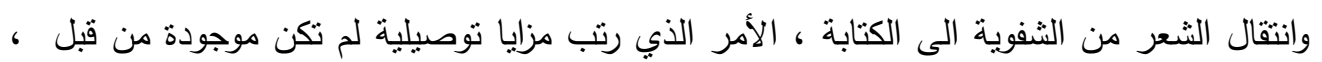

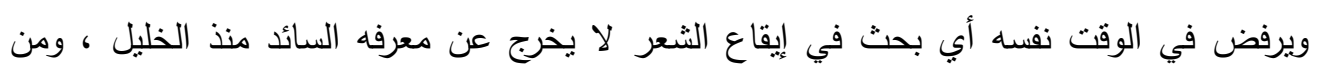
المقولة السائدة بأن الشعر كلام موزون مقفى • (r^)

وفي الوقت نفسه يرى أن على قصيدة النثر أن تجيب عن أمرين ، أولهما عن سؤال الحداثة ، والاخر عن علاقة الثعر بالنثر ، بمعنى أن إسقاط الوزن من قصيدة النثر ، بتوجب عليها البحث عن إيقاع بديل

" يوائم بين الشعر وما سواه ، ويصل عناصر النص ببعضها إيقاعيا وفق محددات جديدة تتاسب ما

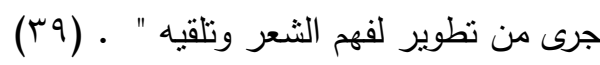

ومن ثلك المنطلقات الحداثوية ، حاول الصكر دخول عوالم قصيدة النثر ، ليستتق نصوصها وصولاً الى مزايا جديدة لهذا النوع الجديد خارجة عن الفهم التقليدي للنص من بينها :

1- إنها قصيدة قراءة تخاطب عبر الجسد الورقي عيني القارئ لا اذنيه ـ وهذا يرتب مزايا كثيرة منها استثمار سطح الورقة للتوصل دون الحاح على الوسائل الثفاهية كالقافية والوزن والصيغ والقوالب اللغوية الثفاهية .

ץ- - إنها تستقيد من نصيتها وإفلاتها من التجنيس في الإفادة من الخصائص السردية ، ولاسيما

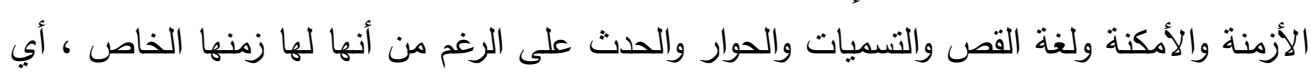
الزمن الثعري الذي لايرتبط مع الزمن التاريخي . 


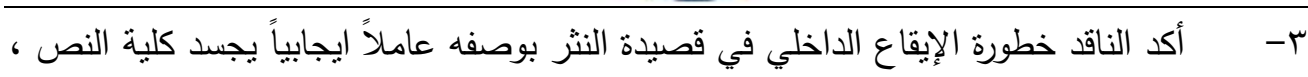
لأنه يحتوي العناصر كلها ، ويمكنا تقصيه ومراقبته في البياض الورقي من الدلالات التي تحيل إليها الألفاظ.

ع - إنها نولا ايحاءات لا معاني لها ، مما يؤكد كون قصيدة النثر دلالية ـ ويساعد على حرية

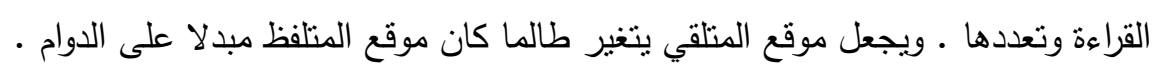
0- إنها قصيدة كلية لا جزء فيها يغني عن سواه كما أنها لا ندرك بالملفوظ وحده ، وهي لذلك

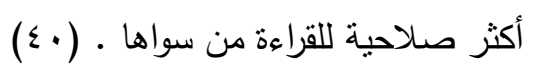

إن هذه الخصائص ليست فنية محضة ، بل في كثير من الأحيان تتخذ من آليات نظرية ( القراءة

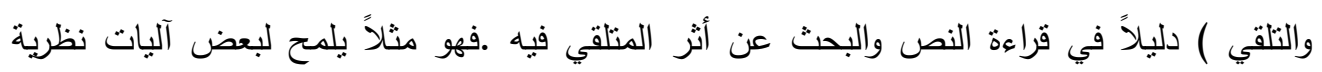

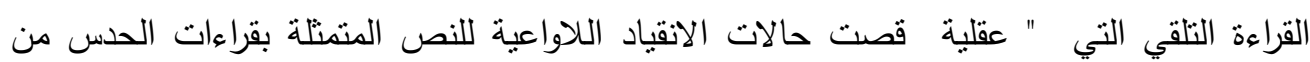

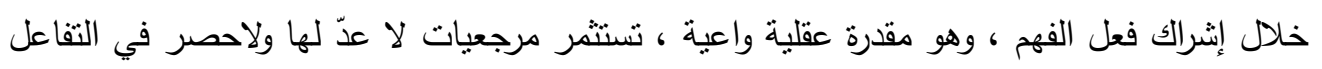

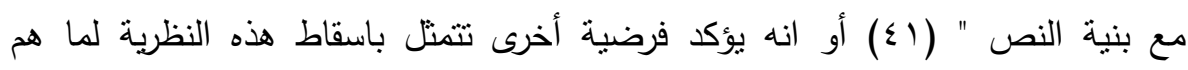

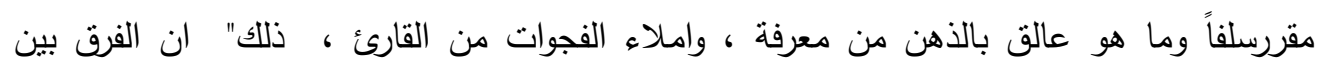

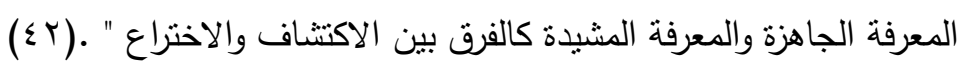

وفي دراسة أخرى أكثر نضجاً للصكر تضدنها كتابة ( حلم الفراشة )(بـ) عنوانها "الثتعرية

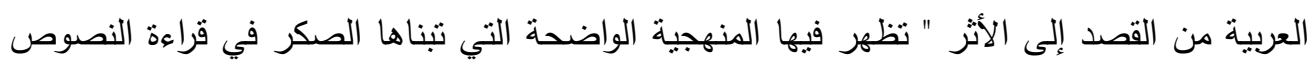

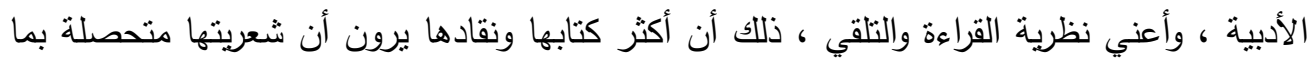

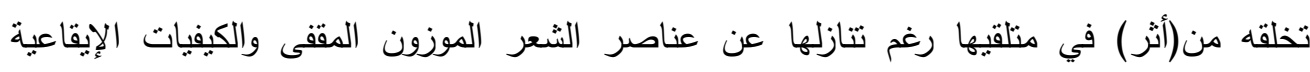

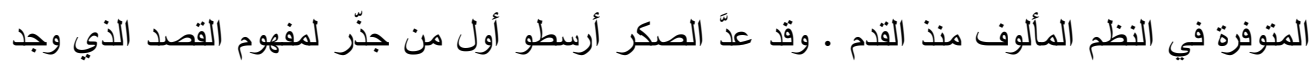

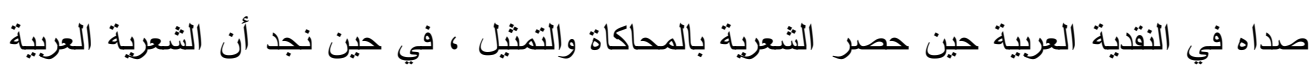

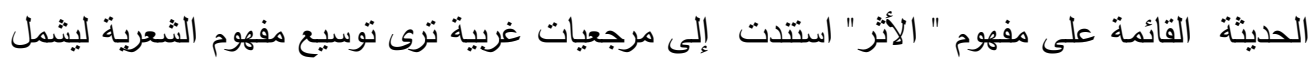

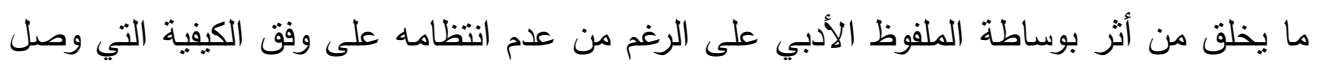

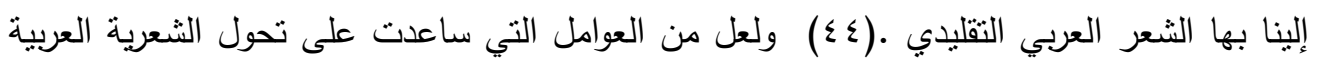

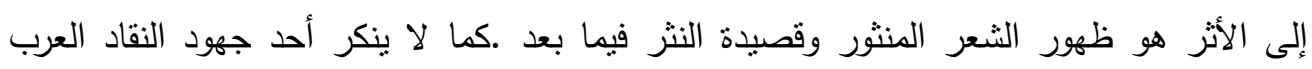




\section{مجلـــة كليــة التربيــة}

الدستتيرين بالمناهج النقدية الحديثة ولاسيما مناهج القراءة والتلقي التي نبهت إلى (الاثر) عبر إحباء

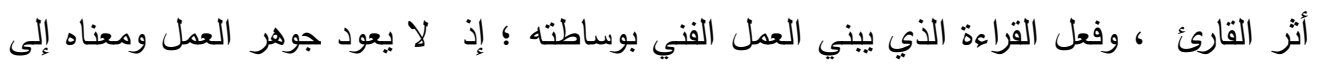
النص ولا إلى كاتبه بالضرورة ؛ بل إلى تلك الاجراءات التي يتم فيها التفاعل بين تخيل القارئ

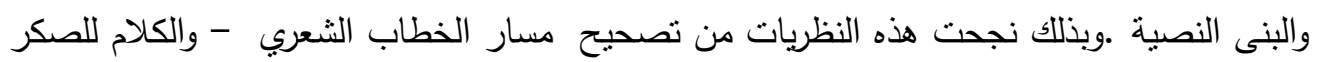

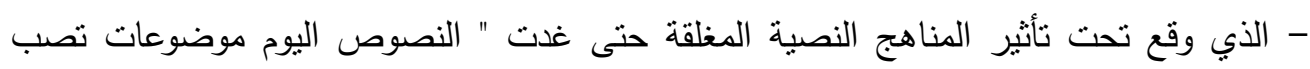

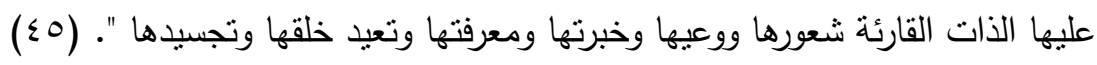

ويأخذ الصكر على كتاب قصيدة النثر ونقادها عدم الالتفات إلى التتاقضات التي كانت توسم قوانينها المقترحة بدءاً من اسم قصيدة النثر المحيل إلى ضدين : شعر ونثر ، مروراً ببنائها العام

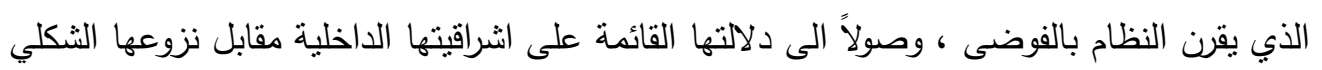

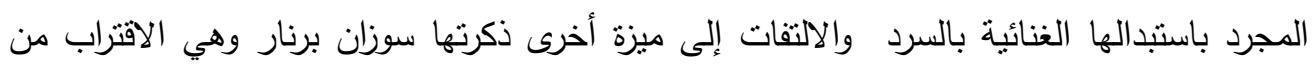

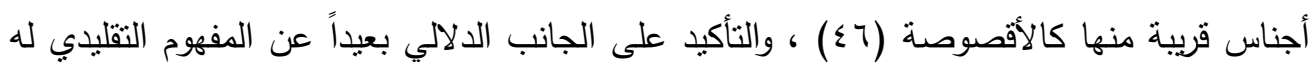

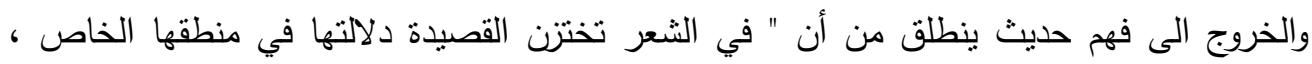

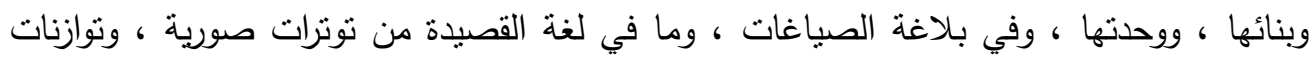

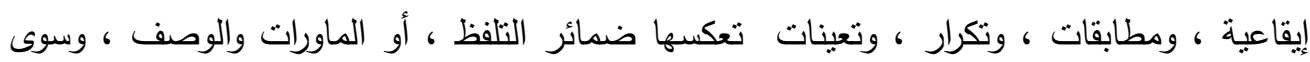

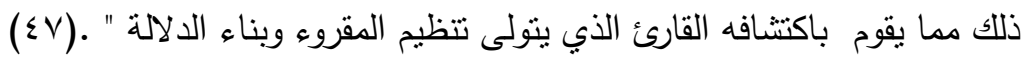

ومن التتاقضات الأخرى التي اشار اليها هي الفوضى الظاهرة في قصيدة النثر التي لا

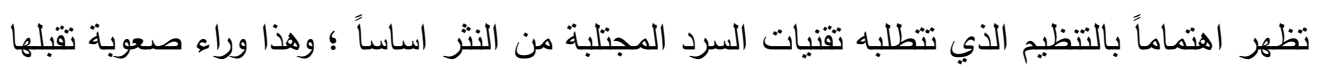
وتلقيها.

وانسجاماً مع نوجه الناقد ومنهجيته التي تميل في قراءة الظواهر الادبية والنصوص الإبداعية

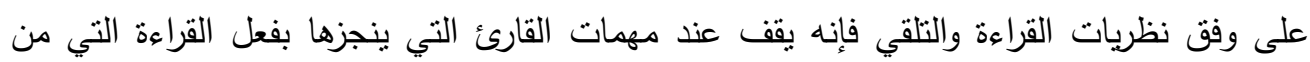

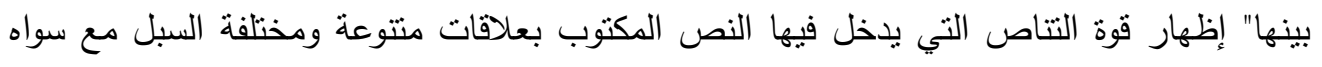

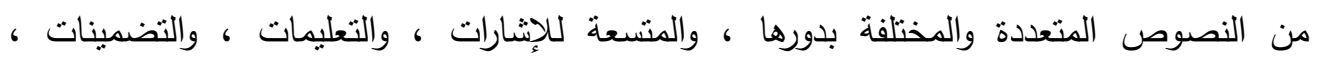

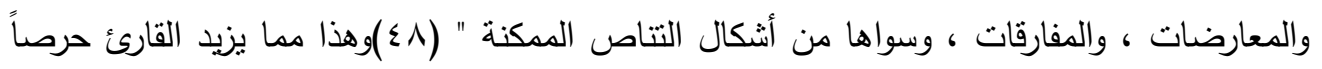
على الاحاطة بالكثير من الامور المعرفية الني يفتقد اليها كثير من القراء فتغيب عنهم جماليات 
القصيدة وحكمتها ، ولعل ذلك سبباً مهماً وضع الصكر يده عليه في ابتعاد القراء عن قصيدة النثر التر

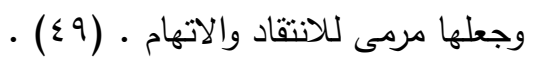

وظاهر في هذا ان الصكر يحاول ان يطبق آليات القراءة والتلقي على قصيدة النثر التي منها معاينة العلاقة بين أفق العمل الادبي وأفق الجمهور التي ينبثق عنها مغزى جديد ، وهو جلَّ ما أكده (إيزر) عندما قرر بأن العمل الأدبي ينتكل من خلال فعل القراءة ، وأن جوهره ومعناه لا ينتميان إلى النص ، بل إلى العملية التي تتفاعل فيها الوحدات البنائية النصية مع تصور القارئ ومن خلال اثتغال القارئ به " . (0. (0)

ونفهم من ذلك أن التتاقض الحاصل بين الثعر والنثر يجعل من الصعوبة ايجاد نص "نثر شعر " من دون يغادر غنائيته التلقائية الفجة ، ويتوسل بثقافة النص الثعري بديلاً لها ، ويلزم

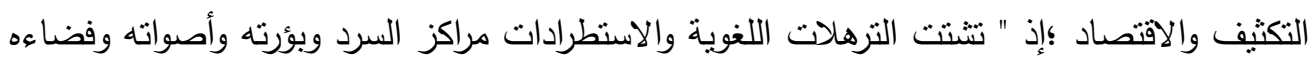
وتسمياته ويكون النثر في حالة كهذه متجهاً إلى (أثز) المكتوب في القارئ لا إلى (القصد) من الاثر الادبي " .(1) والانصهار في بوتقة واحدة انصهاراً قوياً تذوب فيه خصائص ما يقذف النص الى مصهره من استعانات ورؤى وعناصر ولا يظل لها وجود مستقل يمكن انتزاعه او سلخه .. ويجمل الناقد التتاقض المفهومي في مصطلح قصيدة النثر من خلال المقارنة الآتية :

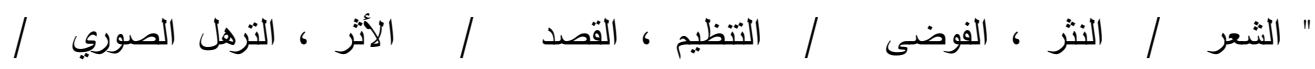
التكتيف البنائي ، الأداء المعنوي / الانجاز الدلالي ،الغنائية / / السرد ، الواحدية النصية

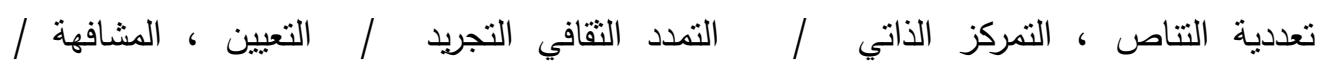

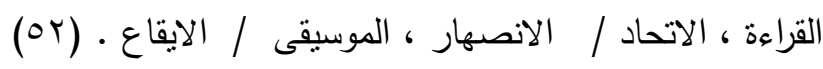

وواضح - أن الناقد - يجترح لقصيدة النثز خصائص معينة بعضها وردت عند دعاة هذا النوع ، وبعضها من استتباط الصكر نفسه ، ولكن هذه الخصائص ينبغي ألا تكون إطاراً تقتل الثاعرية في حدوده ، وهو ما يخلق معوقات جديدة لا تختلف عن تلاك المعوقات التي خرج عليها الثاعر القديم ، كما تخرج عليها وتتمرد- اليوم - قصيدة النثر. ومن جهة اخرى يقترح الصكر بعض جه الاجراءات لقراءة النص الجديد ، وهي كما يأني : 
1- منظور السرد المهيمن على قصيدة النثز.

ץ- مهمة تتظيم المقروء النصي التي يقوم بها المتلقي.

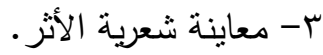

ع - ملاعمة الفوضى والتظظيم في النصوص.

ه- تعقب الدلالة داخل النص لا المعاينة المجتزأة.

צ- ملاحظة التتضيد الخطي للنص ومفاتيح القراءة كالعتبات النصية وسواها.

V-تغيير أفق القراءة لتلمس الايقاع الداخلي البديل عن الموسيقى الخارجية.

^-تجاوز أفراد النصوص الى النوع نفسه .(r)

إن ما يلحظ هنا ، ان الصكر لايركز على القارئ فحسب ؛ وإنما يركز جلَّ عنايته على عملية التلقي بشكلٍ عام ، وهو في هذا يتابع (ياوس ) الذي اهتم بعملية التلقي في شموليتها على خلاف إيزرالذي توجه صوب العلاقة بين المتلقي والنص مع عناية كبيرة بالقارئ بوصفه فرداً (عه)

ولعل من المفيد القول : إن القراءة المنهجية الواعية كانت نرافق الناقد ولم يتخل عنها ، فلم بطلق احكامه النقدية من دون أن يسوغها من ذلك قوله : بتجبيل شعراء قصيدة النثر، وعدم

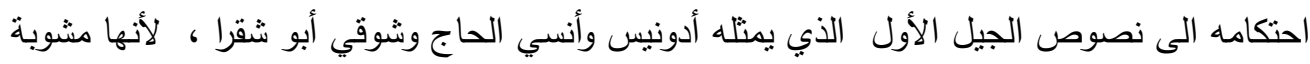
بكثير من أخطاء البدايات ، والاتكاء على نصوص الجيل الثاني الذي نضخت على ايديهم "بفعل تراكم الكتابة ، وترجمة النصوص ، ودرجة الوعي بقصيدة النثر على مستوبين : كتابتها من قبلهم ، أو تلقيها من طرف القراء والنقاد ".(0)

ويؤشر الناقد - هنا - جملة خصائص للجيل الثاني ، من بينها : أنه ينصرف الى داخل النص ، وييني بلاغة النص الحديث على حياد لغوي وصوري وعاطفي ظاهري ، وينسلخ عن تلك الغنائية التي كانت تلازم نصوص الجيل الأول أدونيس ؛إذ " تهيمن (الأنا) الثعربة على الخطاب وتحرك وكي وكي 
القصيدة ، بما في الغنائية من موسيقى ومباشرة وصوت عال "(40) ، وذلك من خلال إخفاء

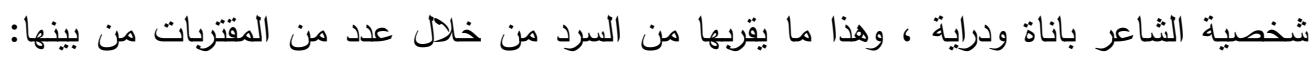

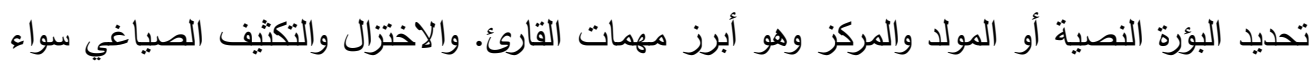
ما اتصل بطول القصيدة وقصرها أم بدلالتها ـ وبنية التكرار بشتى أساليبها .والبناء المتتامي تجسيداً

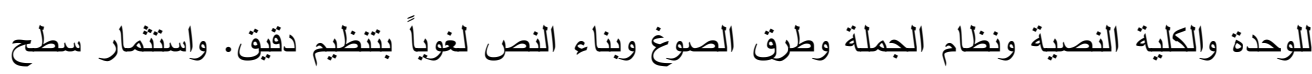

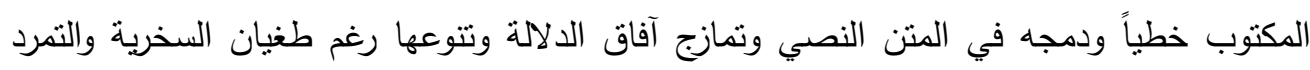

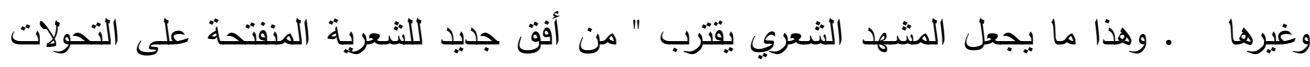

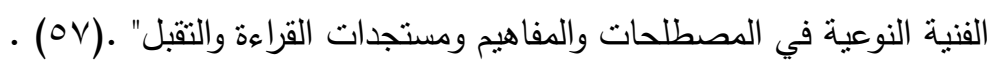

واضح تعلق الناقد بآليات القراءة والنلقي وفهمه الحقيقي لها ، فهو يضع للقارئ جملة مهام ، ينبغي

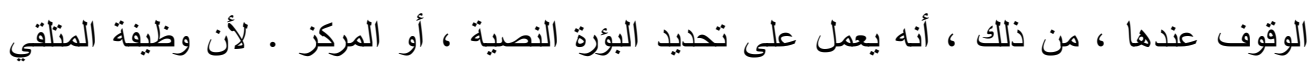

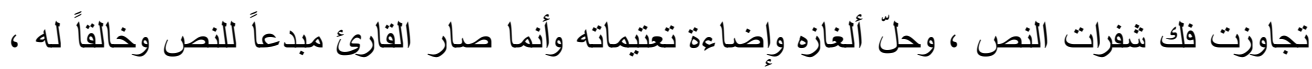
يضفي عليه من روحه ما يرفعه إلى مصاف النصوص الأدبية الراقية .

لقد حاول في هذه الدراسة ( الثعرية العربية من القصد الى الأثر ) " استتراف ماهية الثعرية

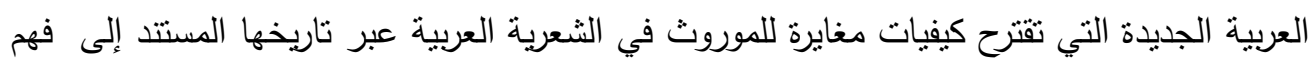

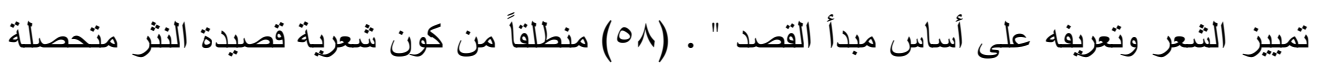
بما تخلقه من أثر في متلقيها على الرغم من تتازلها عن القدم .

وقد كان هذا الفهم متأنياً من الصلات بالمناهج الحديثة ذات الفاعلية الثديدة ومنها مناهج القراءة

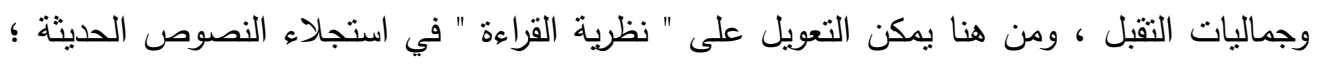

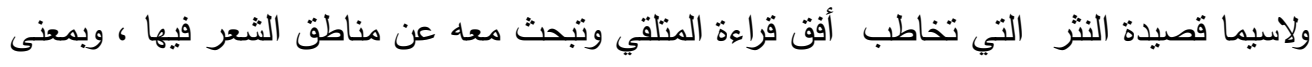

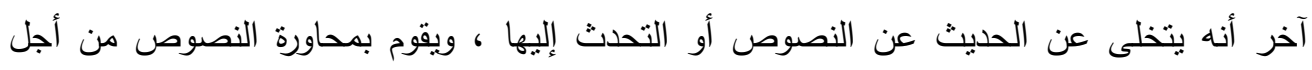

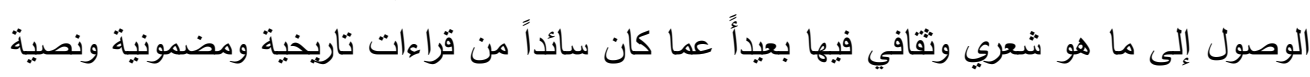

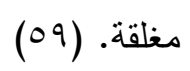

ولعل واحده من صور الحوارية التي يقيمها القارئ مع النصوص أنه يتولى تنظيم النصوص المقروءة

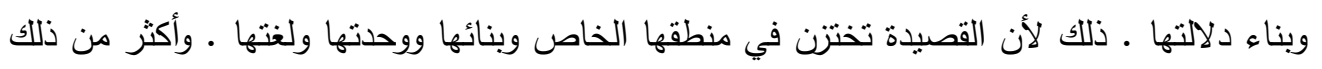




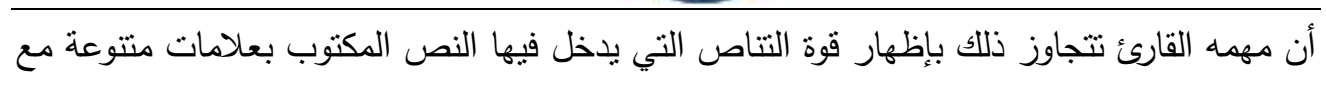

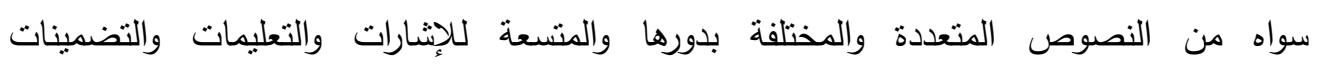

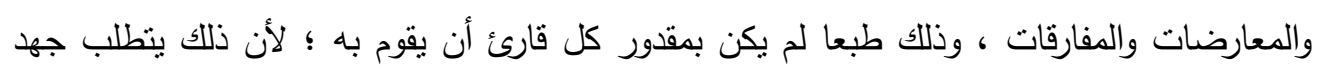

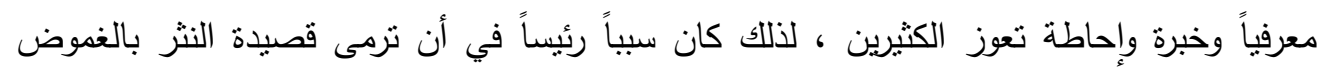

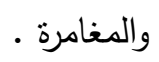

ومن جهة أخرى يرصد الناقد أسباب صعوبة تقبل قصيدة النثر وتلقيها ، فيجد أن تقنيات السرد

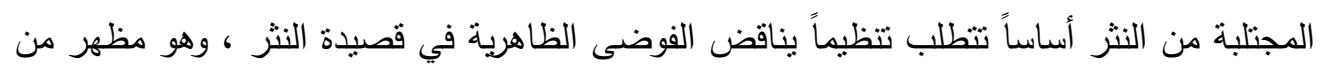

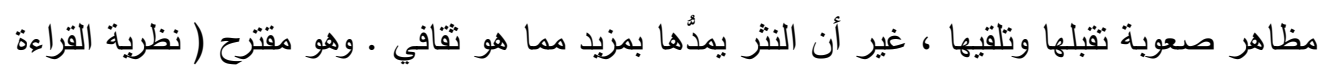

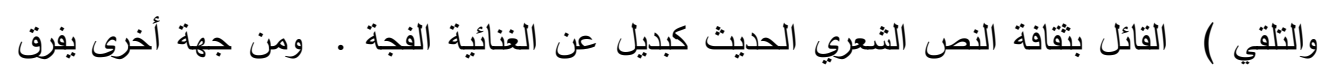

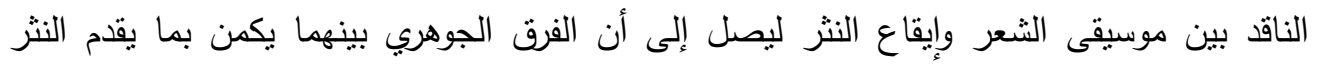

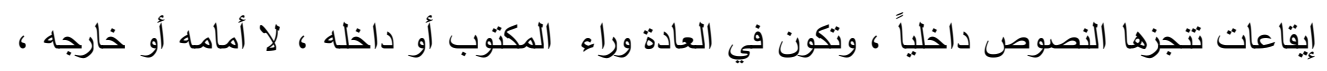

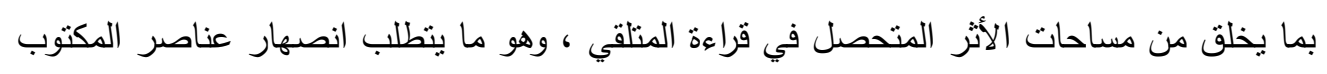

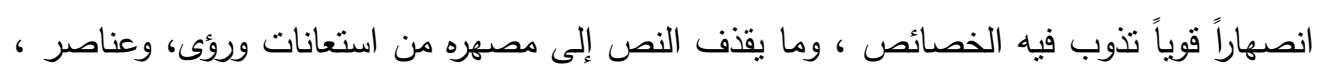

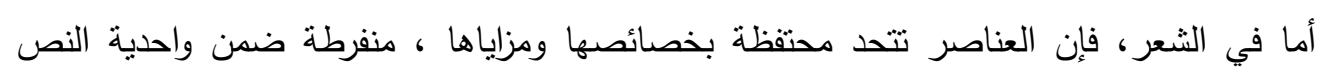

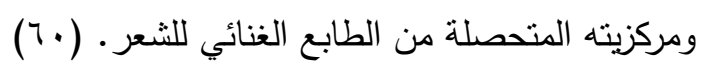

واستتاداً إلى مقترحه الأخير فإن الصكر يدعو إلى تجاوز الجيل الأول لقصيدة النثر ؛ لأنه ارتبط

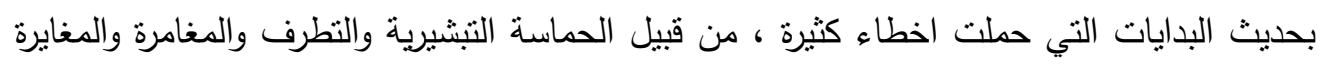

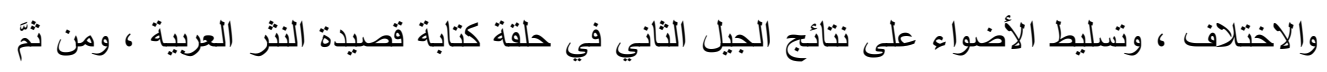
استتطاق نصوص هذا الجيل ، ليصل إلى أهم المظاهر النصية فيها ، وهي كما يأني :

$$
\text { 1- تحديد البؤرة النصية أو المولد وهو أبرز مهمات القارئ · }
$$

r- الاختزال والتكثيف الصباغي سواء ما اتصل بطول القصيدة وقصرها أم بدلالتها .

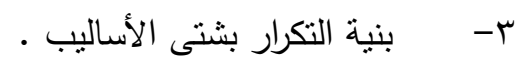


0- تحرير الواقعة من تسلسلها وادماجها في سياق الوقائع الثعرية .

7- اعتماد التتاص واذابة عناصره المتتوعة رمزاً واشارة تضميناً في النص الجديد .

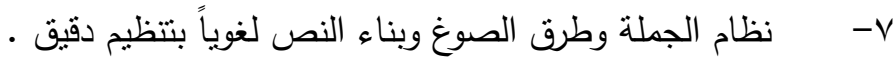

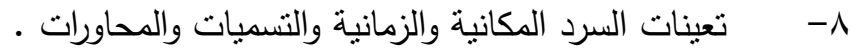

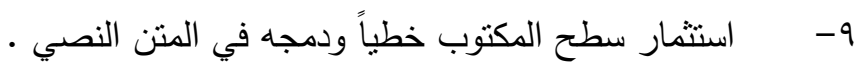

• - تمازج آفاق الدلالة وتتوعها على الرغم من طغيان السخرية والتصرد. (1)

ويخلص بعد ذلك الناقد إلى أن ما تقدم يمكن أن يمهد إلى ظهور أفق جديد للشعرية العربية المنفتحة على التحولات النوعية في المصطلحات والمفاهيم ومستجدات القراءة والتقبل .

ومما يقال في هذا المجال : إن الناقد وعلى الرغم من تبنيه نظرية القراءة والتلقي في هذه المرحلة من مراحل تطوره النقدي والفكري ، فإنه لم يحاول استتطاق النصوص ووضع اليد على المظاهر النصية التي تنبير إلى منتنيات النظرية ـ فقد خلت دراسته من النصوص الثعرية الا القليل منها ، وجاءت بعض أحكامه في سياق التظظير النقدي الذي لا يعززها أب نص شعري . على الرغم من معرفتتا بإحاطة الناقد وقدرته على قراءة النصوص واستتطاقها واستخلاص خصائصها النصية والفنية وانساقها التقافية. ومع ذلك فقد حمل هذا الناقد لواء هذه النظرية في النقد العربي وصار لله ميسمه الخاص في معاينة النصوص الادبية ، اذا ما قيس بنقاد اخرين بقوا منقوقعين في مناطق نقدية صارت اليوم في حكم الماضي ، ولم يعد لها ذلك الحضور ، ولاسيما تلك التي ارتبطت بأيدولوجيات فكربة وسياسية .

وفي الكتاب نفسه يقف "الصكر" وقفة مهمة إجرائية عند الايقاع الداخلي في دراسته موسومة بـ ( الايقاع والايقاع الداخلي في قصيدة النثر ) التي اختلفت عن كثير من الدراسات التي تتاولت ايقاع قصيدة النثز ولم تتمنل ولو بنص واحد يثبت أو ينفي الايقاع عن هذا النوع الذي أخذ الحديث يتجدد حوله سلباً أو ايجاباً في الوقت الحاضر . 
ويعترف الناقد في مستهل دراسته بصعوبة" الخوض في الايقاع ، كونه يقع عند متلقي

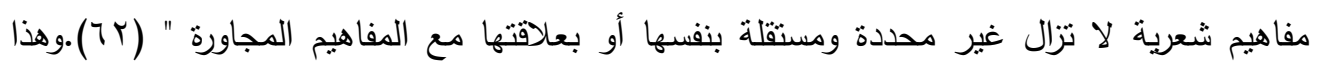

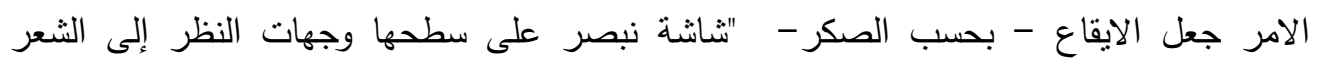
".(T) ولكن الخوض في الايقاع يجب ألا يبقى في إطاره القديم وعليه أن بيتوسل بنظريات القراءة والتلقي بعد " تغير القتوات الاتصالية ، وانتقال الشعر من الثفوية الى الكتابة ، الأمر الذي رتب مزايا

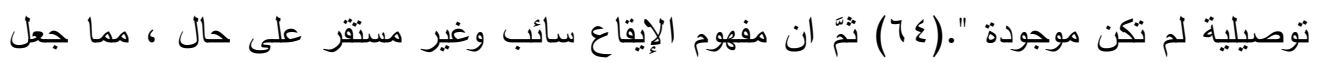

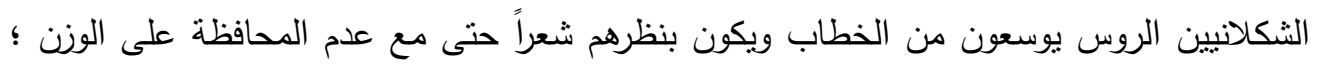
فما الوزن إلا صورة من صور الإيقاع ، فهناك كثير من الوسائل التي تحقق الإنسجام وهو المبدأ الذي يؤديه الإيقاع ، وبذلك تتوزع مهمة الإيقاع الفنية بين الثاعر خلال الكتابة ، القارئ عند إنجاز قراءاته .(0) ولاثك ان تلك الروئة التي تبناها الصكر هي جزء من شغفه بنظريات القراءة والتلقي

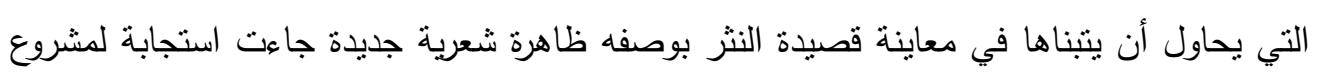
الحداثة .

لقد وجد الصكر في الإيقاع الداخلي تعويضاً عن الايقاع الخارجي الغائب عن النصوص الحديثة ، ويكون لديه بموازاة الايقاع الخارجي في القصيدة الكلاسيكية ، إذ يقول إنّ"الإيقاع الداخلي يأتي غالبا

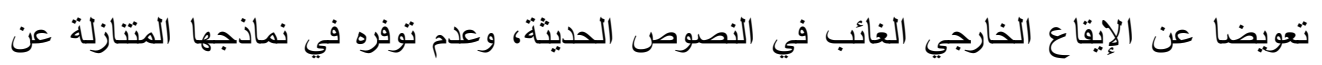
صدى القافية ورتابة التفعيلة.. مما يجعل الإيقاع الداخلي يؤدي وظيفة تكوينية بإزاء المهمة الإطارية

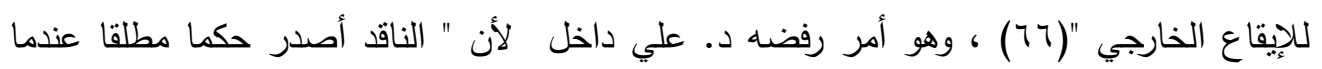
افترض منذ البدء أنَّ ما سمّاه الإيقاع الخارجي (الوزن) أصبح غائبا عن النصوص الحديثة ، وكأنه

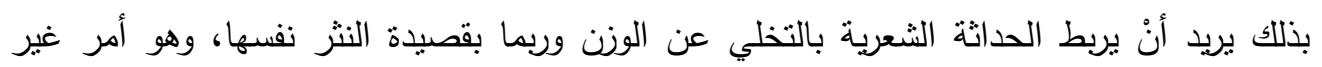
دقيق، لأن الحداثة لا يمكن أنْ ترتبط بشكل معين دون سواه، ولعلنا نستطيع أنْ نستدل على ما قلناه بأنَّ عدداً من شعراء قصيدة النثر العرب ( وهم دعاة متحمسون للحداثة الثعرية ) ما زالوا يكتبون القصيدة الموزونة ، وفي مقدمة هؤلاء أدونيس نفسه ، فكيف يكون التخلي عن الوزن مقياسا للحداثة

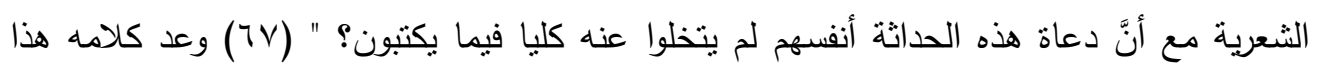
"انحيازا واضحا الى شكل كتابي اعتمادا على معيار مسبق هو التخلي عن الوزن، وهذا الموقف قد لا لا هذه يكون مختلفا عن موقف خصوم قصيدة النثر ورافضيها ".(11) 


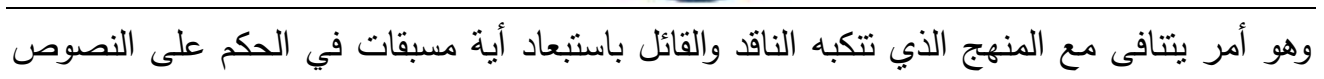

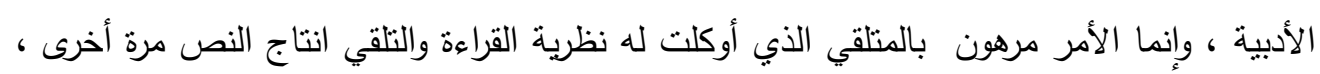

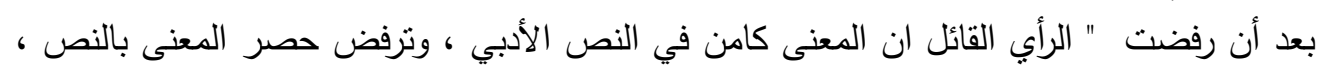

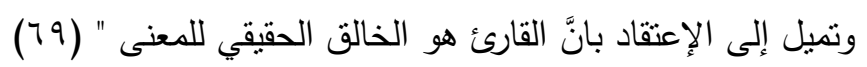

إن الصكر لم يقل بأنه غائب عن الثعر كله ؛ ولكنه ذكر النصوص الحديثة ؛ لانها تقترن بقصيدة

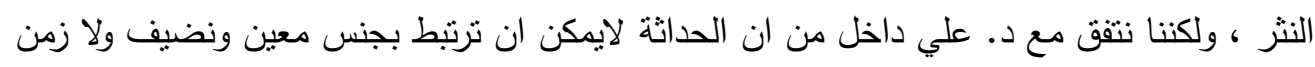

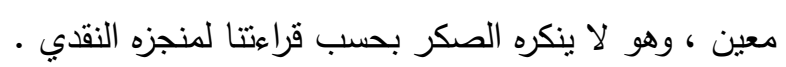

ومن جانب اخر نجد أن الصكر يحمل على قصيدة التفعيلة بشكل خفي ويحاول سلب ثورتها على عروض الخليل حين يجد " أن الوزن الحر غير كاف لكسر رتابة الايقاع الخارجي للقصيدة

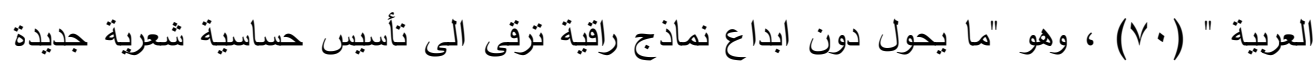

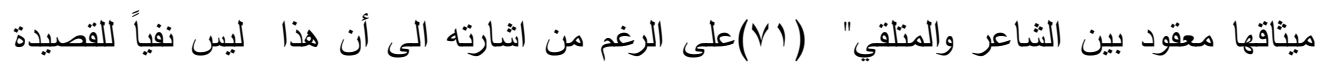
المكتوبة على التفعيلة ؛ بل وصفاً لخصائصها الموسيقية .

ومن جهة أخرى يجد "الصكر" أن معالجة موضوعة الايقاع في قصيدة النثر يجب أن

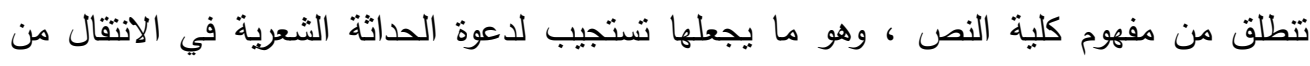

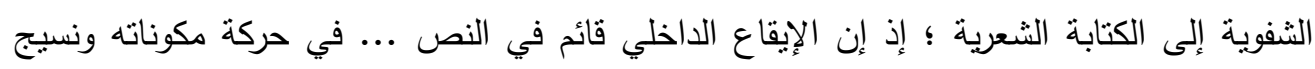

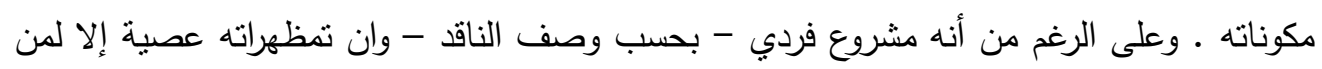

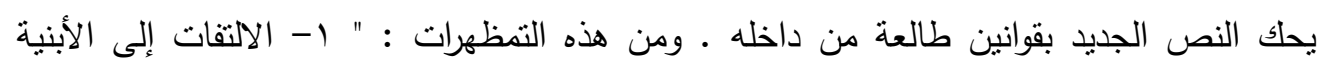

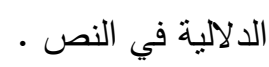

r- الانتباه إلى إيقاع الفكرة والصورة والمضمون والدلالة . r- استثمار تقنيات الكتابة الثعرية . ع - استتباط الجملة الثعرية الكبرى التي يقولها النص • (VY)." استخراج الثعر مما هو خارج النص 


\section{مجلــــة كليــــة التربيــــة}

أحسبُ أن قول الناقد إن الإيقاع مشروع فردي فيه إثكال واضح ،ذلك أنه مما يمكن أن يتوصل إلى بعض تمظهراته بأدنى معرفة بخصائص اللغة العربية والقصيدة ليست فعلاً فردياً حتى وإن خرجت

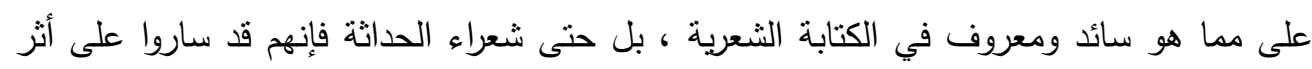
وهو مما يعني أن فعلهم لم يعد فردياً فقد صار فعلاً جمعياً .

ثم ينتقل بعد ذلك إلى بيان مزايا قصيدة النثز بعد استقراء لنصوص شعرية ومتابعات نقدية لمنظريها الاوائل ومن جاء بعدهم ، ومنها السكون الذي يحدٌ من طغيان الكلمة ـ. كما أن كتاب قصيدة النثر وجدوا في التراث العربي دافعاً لاستجلاء الثعري من النثر لتعويض غياب الوزن والقافية ولتحقيق شعرية النص و

ولم يتخلص الناقد تماما من هيمنة المناهج السياقية التي تدعوه دائما الى الوقوف على الاسباب المؤدية إلى ثقشي الظواهر الادبية ؛ ولذلك نجده يفرد مكانا قصياً من دراسته لممهدات ايقاعية هيأت أرضية صالحة لتحقيق الايقاعات الداخلية في قصبدة النثر منها الشعر المترجم من اللغات الاجنبية والخلط العروضي أو الاختلاط بين تفعيلات كثر من بحر ، والتدوير ، والنثر الفني والعامية الدارجة ، وتغير البنى اللغوية والنحوية ، وممهدات محايثة تدخل فيها عوامل متعددة منها مظاهر تحول الاشكال الفنية ( رسم ، وسينما ،موسيقى ، غناء، مسرح ، رواية ، قصة ). (VT) والحقيقة أن كثيراً من الممهدات التي ذكرها الصكر هي التي كانت تسعى إلى الاقتراب من الثعر لتصنع شعريتها ـ مثل ذلك الاشكال الفنية .

ويميز "الصكر" بين ثلاثة أنواع من الإيقاع القائم على التوازي وهي : التكرار أو الإعادة

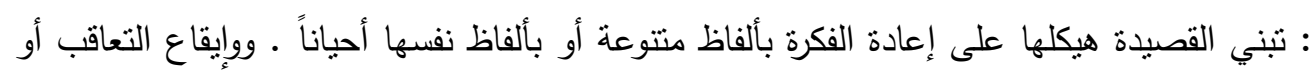
النمو المتوالي ، وتكون للجملة الثعرية أجزاء صغرى يؤدي أحدها إلى الآخر وصولاً إلى النهاية .والنوع الثالث: وهو الذي يربط العبارات المتجاورة ربط السبب بالنتيجة ـ ثم يضيف الى تلك الانواع نوعاً آخر هو إيقاع التضاد والتتاقض • وبعد ذلك يقترح "الصكر" لاستجلاء إيقاع قصيدة النثر القراءة بمفهوم البؤرة والموجه أي بمفهوم المركز الذي يبني له أغلفة تتسع من حوله لتبتعد عنه رغم انبثاقها منه ، وعودتها إليه ملامسة ومفارقة ـ من ذلك كله يخرج الناقد بجملة نتائج ، وقد أوجزها بما يأني : 
1- الإيقاع أسبق من العروض والوزن وأشمل منهما .

r- لا يحدد الايقاع الداخلي خاصة تحديداً حصرياً ، لأنه شخصي ومتغير •

ب- يتغير الإيقاع كلياً بتغير البنى المكملة ثقافياً .

ع - لا يظهر الإيقاع الداخلي مجسداً بالإنشاد بل بالقراءة وما يترتب عليها من مزايا.

0- وهو إذن مهمة فنية ، تأليفاً ، وجمالية استجابة وقراءة ـ وتلقياً .

7- ثراؤه في هدم أسوار الثعر والنثر للانتفاع من إيقاعات مختلفة .

- سيظل الخلاف حوله طويلاً ؛ لأنه مركز تقاطع لعدة قضايا منها : الشعرية ، والحداثة .

^- لكل قصيدة إيقاعها الذي تصنعه المهيمنة سواء أعلى المستوى الدلالي أم الصوتي أم التركيبي

الخاتمة

ومما تقدم يشعر القارئ للمدونة النقدية لحاتم الصكر انه أمام ناقد مسلح بالمعرفة والثقافة

الممتزجة بالروئة الممنهجة التي شذبتها وصقلتها الدراسة الاكاديمية ، لذلك نحن نشعر بروح المنهج الذي تبناه الناقد أعني "نظرية القراءة التلقي" وهو ما جعله يؤكد على أثز القارئ ، وفعل القراءة بوصفهما سبيلاً مهماً في توصيل النص واجتذابه من شعرية القصد إلى شعرية الأثز ، وان تعلق الناقد بسبر أغوار النصوص لا يمنعه من يستخلص بعضها السمات والخصائص لقصيدة النثر العربية التي جعلت من تتظيراته واجراءاته محط احترام كتاب قصيدة النثر ونقادها ، واكثر من ذلك يمكن أن نشير إلى أنه في هذه الدراسة أو في غيرها قد وهب أكثر منجزه النقدي لقصبدة النثر مما يجعله أحد أهم نقادها ومنظريها بامتياز - لفيز

وأخير يمكن القول: لم يبق موقف الناقد حاتم الصكر من قصيدة النثر في حدود القبول فحسب ؛ بل نراه قد عبر عن ذلك ، بروئة نقدية واضحة المعالم ، سواء على الصعيد التتظيري أو التطبيقي ، 


\section{مجلــــة كليـــة التربيـــة}

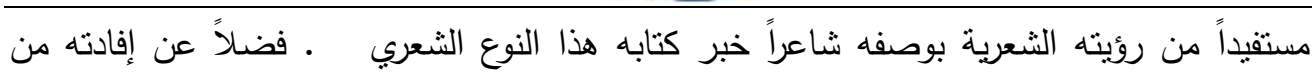

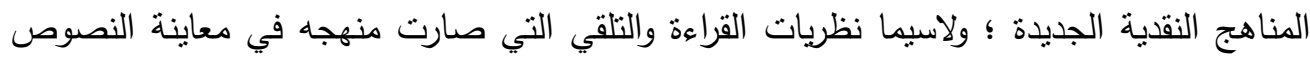

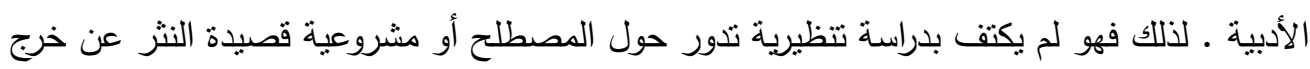

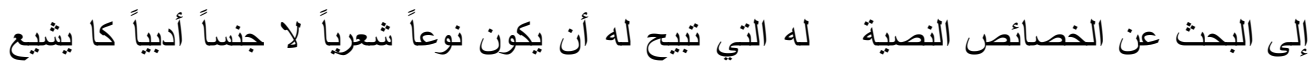
بعض النقاد ممن يمسكون العصا من المنتصف .

وانساقاً مع منهجيته في قراءة النصوص الأدبية ، فإنه حاول جاهداً بيان أسباب ضعف تلقي قصيدة

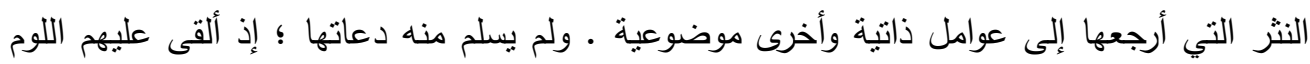

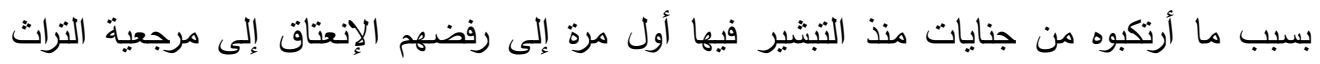

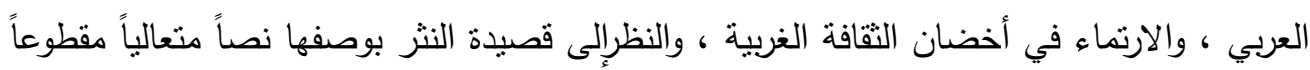
عن أية مرجعية تراثية .

كما أن من المهم القول إن الصكر انفتح على الساحة الشعرية العربية ، ولم يق حبيس التجربة

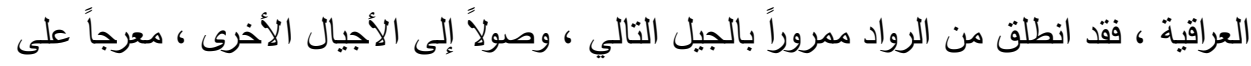

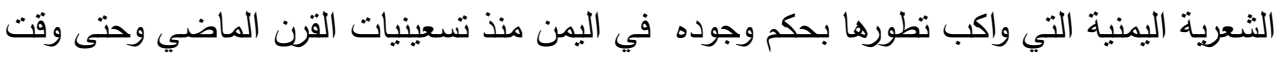

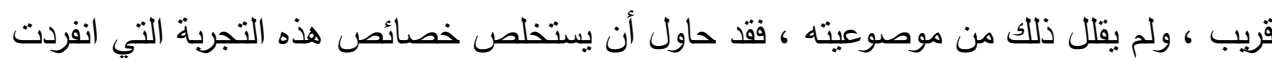

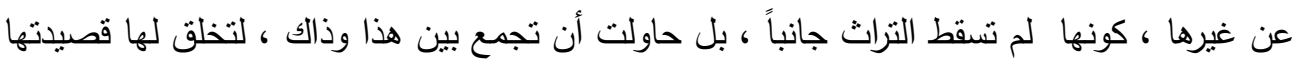

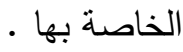




\section{الاحالات}

: في غيبوبة الدكرى ، دراسات في قصيدة الحداثة ، مجلة دبي الثقافية ، 9 ، . . 7 :

(Y) : قصيدة النثر والاحتمالات المؤجلة ، حاتم الصكر ، مجلة الاديب المعاصر ، الاتحاد العام للأدباء والكتاب في العراق ، العدد اعـ ، كانون الثاني ، •99 ام : 1. 1.

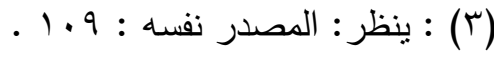

( () : بنظر : المصدر نفسه : سار-110

(0) : ينظر : المصدر نفسه : 110

$$
\text { (1) (1) : المصدر نفسه : } 117
$$

. 111 - 111 : (V)

(^) : الثعر العربي عند نهايات القرن العشرين ، المحور الرابع ، اتجاهات نقد الثعر العربي المعاصر ، اعداد عائد خصباك ، اشكالية القارئ في النقد الالسني ، د. ابراهيم السعافين ، مهرجان المربد الشعري التاسع ، 919 ام : 10 إل

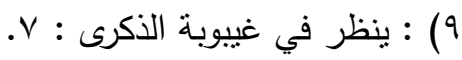

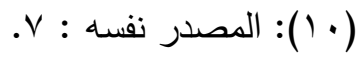

(1) (1) : القارئ في الحكاية ، أمبرتو إكو ، ترجمة أنطوان أبو زيد ، المركز الثقافي العربي 999 ام :

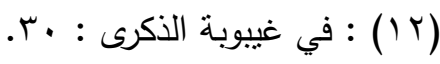

(T (): لم يثر الصكر إلى مكان وجودها في منجز ( جبرا ) : ينظر : المصدر نفسه : • . . 
( ) ( ) : ينظر : نقد أدبي حديث ، مفاهيم ومصطلحات وأعلام ، الأستاذ الدكتور حامد صادق قنيبي

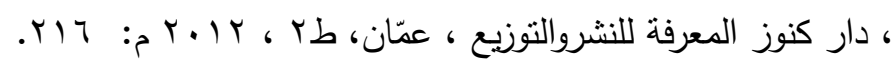

(10) (10) : بنظرالمصدر نفسه : بr.

$$
\begin{aligned}
& \text { (7 (1) : المصدر نفسه : ץr. } \\
& \text { (IV) : لن ، انسي الحاج : (IV) }
\end{aligned}
$$

(1) (1) : مسنقبل الثعر وقضايا نقدية ، د. عناد غزوان ، دار الثؤون الثقافية ، بغداد ، طاه، .

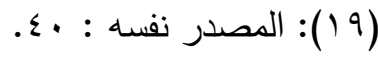

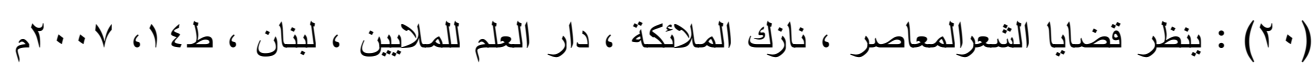
RTV-rIT:

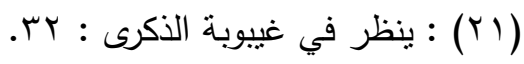

: الثعرالعربي عند نهايات القرن العشرين ، تحديث النقد الشعري : روية... مراجعة...

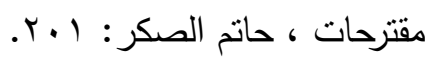

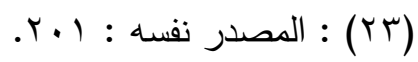

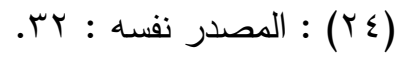

(ro) : الخطاب النقدي حول السياب ، د.جاسم حسين سلطان ، دار الثؤون الثقافية العامة ، بغداد ، طا ، V. . .rم : بr. وينظر للمزيد : الإتجاهات والحركات في الشعرالعربي الحديث ، د.سلمى الخضراء الجيوسي ، ترجمة د.عبد الواحد لؤلؤة ، مركز دراسات الوحدة العربية كبيروت ، طاه ، $.71 \mathrm{~T}: \mathrm{s}, \boldsymbol{1}$ 


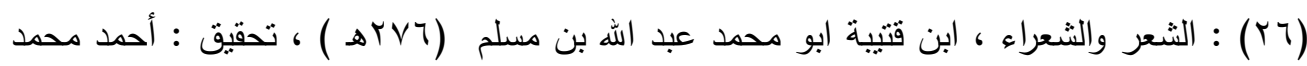

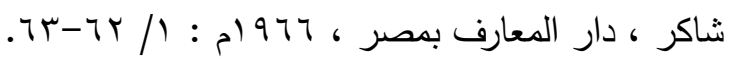

(YV) : قصيدة النثز والاحتمالات المؤجلة ، مجلة الاديب المعاصر ، مصدر سابق.

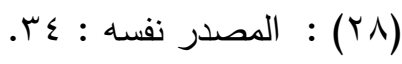

(Yq) : ينظر : قصيدة النثر قصيدة مستقبلية ، دراسة واستتناجات ، ياسين النصر ، مجلة الأديب المعاصر ، الاتحاد العام للأدباء والكتاب في العراق ، العدد اء ، كانون الثاني ، ، 99 ام : 10.

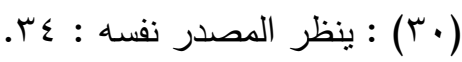

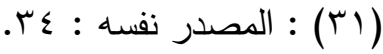

(Yץ) : قصيدة النثر في اليمن ، حاتم الصكر ، مركز الدراسات والبحوث اليمني ، دراسات وأبحاث r

؟ : (

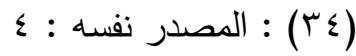

(ro): ينظر الخطاب النقدي حول السياب : اس-عـ.

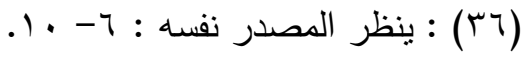

IV : المصدر نفسه (YV)

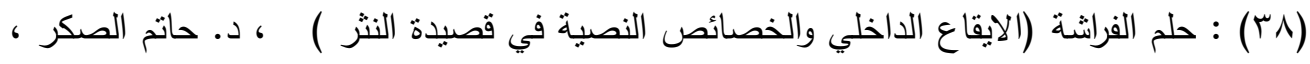

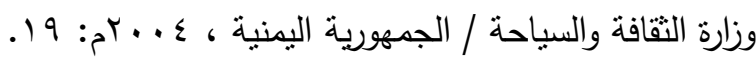

(q)): المصدر نفسه : 19.

نيسان 10

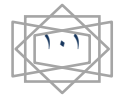




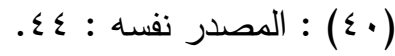

( ( ) : جمالية التلقي من بنية النص إلى بنية الفهم ، د.بشرى موسى صالح ، مجلة الأقلام ، العدد

. Y7: $99 \vee$ م $99-9-V$

.

؟

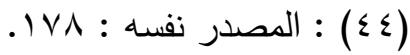

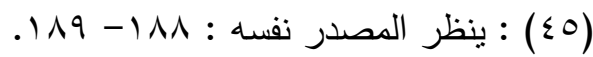

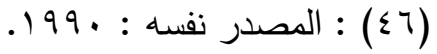

199. : : : المصدر نفسه

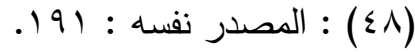

(\$9) : المصدر نفسه : :

( •(0): نظرية التلقي والنقد العربي ، د.غسان السيد ، مجلة الاقلام ، العدد ₹/ آب - أيلول ، لسنة $.17: 51991$

(191)

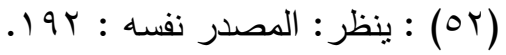

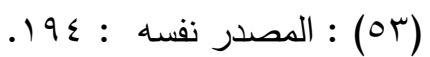

(ع ام) : ينظر نظرية التلقي والنقد العربي ، د.غسان السيد : 1 1.

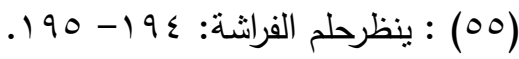


(07) : المصدر نفسه : 197.

(OV) : المصدر نفسه: 191.

(01) : المصدر نفسه: 191- 199.

(09): المصدر نفسه : :

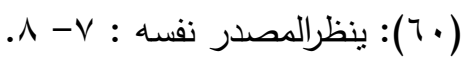

(17):بيظرالمصدر نفسه : 17-11.

(זT) : ينظر : المصدر نفسه : ؟ ؟.

(ז

( ؟7) : ينظر المصدر نفسه : ^^-

(70): المصدر نفسه : V V .

(77) : ما لا تؤديه الصفة ، المقتربات اللسانية والأسلوبية الثعرية ، حاتم الصكر ، دار كتابات ، كوات

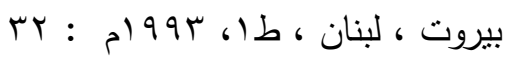

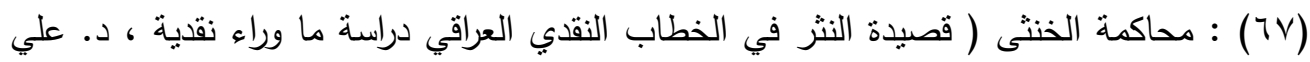

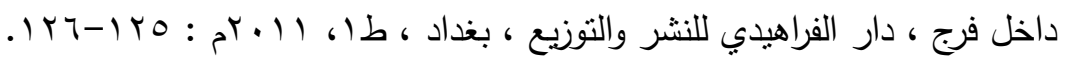

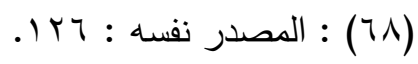

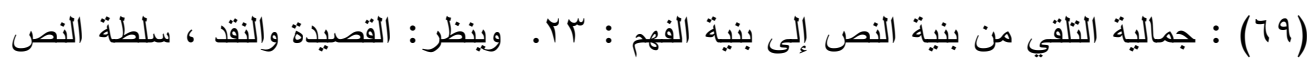

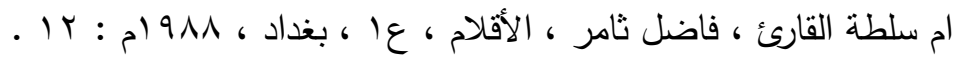

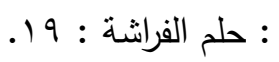




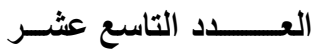

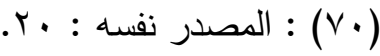

(V) (V): نظرية الاستقبال ، مقدة نقدية ، روبرت سي هولب ، ترجمة وعد عبد الخليل جواد ، دار

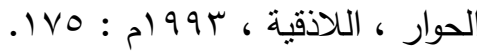

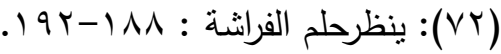

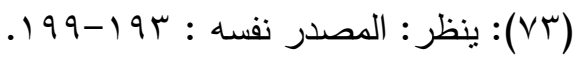


المصادر

- الإتجاهات والحركات في الثعرالعربي الحديث ، د.سلمى الخضراء الجيوسي ، ترجمة

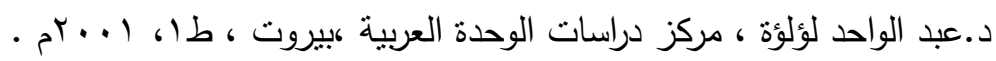

- لم الفراثة (الايقاع الداخلي والخصائص النصية في قصيدة النثر ) ، د. حاتم الصكر ،

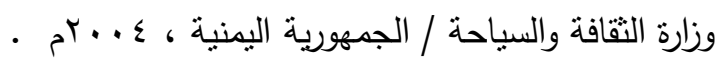

- الخطاب النقدي حول السياب ، د.جاسم حسين سلطان ، دار الثؤون الثقافية العامة ، بغداد

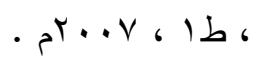

- الثعر العربي عند نهايات القرن العثرين ، المحور الرابع ، اتجاهات نقد الثعر العربي المعاصر ، اعداد عائد خصباك ، مهرجان المربد الثعري التاسع ، 919 ام . - الثعر والشعراء ، ابن قتيبة ابو محمد عبد الله بن مسلم (

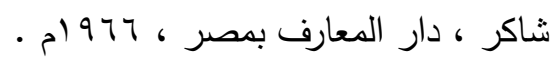
- في غيبوبة الدكرى ، دراسات في قصيدة الحداثة ، مجلة دبي الثقافية ، 9 ، . بم • - القارئ في الحكاية ، أمبرتو إكو ، نرجمة أنطوان أبو زيد ، المركز الثقافي العربي 997 ام • - قضايا الشعرالمعاصر ، نازك الملائكة ، دار العلم للملايين ، لبنان ، طء (، V · . بم . - قصبدة النثز في اليمن ، حاتم الصكر ، مركز الدراسات والبحوث اليمني ، دراسات وأبحاث

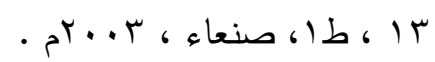
- ما لا تؤديه الصفة ، المقتربات اللسانية والأسلوبية الشعرية ، حاتم الصكر ، دار كتابات ،

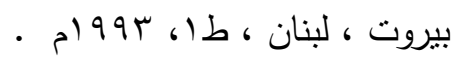


- محاكمة الخنتى ( قصبدة النثز في الخطاب النقدي العراقي دراسة ما وراء نقدية ، د. علي

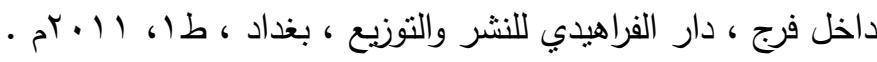

- مستقبل الثعر وقضايا نقدية ، د. عناد غزوان ، دار الثؤون الثقافية ، بغداد ، طاه

. ) $99 \leq$

- نظرية الاستقبال ، مقدمة نقدية ، روبرت سي هولب ، ترجمة وعد عبد الخليل جواد ، دار

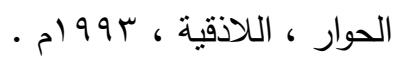

نقد أدبي حديث ، مفاهيم ومصطلحات وأعلام ، الأستاذ الدكتور حامد صادق قنيبي ، دار

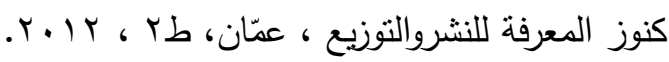

الدوريات

- جمالية التلقي من بنية النص إلى بنية الفهم ، د.بشرى موسى صالح ، مجلة الأقلام ، العدد

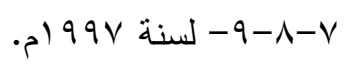

- قصيدة النثز والاحتمالات المؤجلة ، حاتم الصكر ، مجلة الاديب المعاصر ، الاتحاد

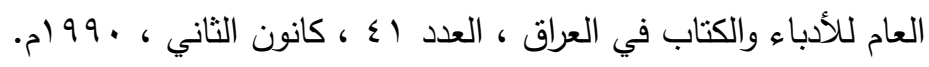

القصيدة والنقد ، سلطة النص ام سلطة القارئ ، فاضل ثامر ، مجلة الأقلام ، العدد ا ،

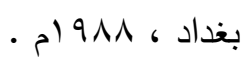

- نظرية التلقي والنقد العربي ، د.غسان السيد ، مجلة الاقلام ، بغداد ، العدد ؟/ آب -

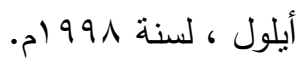

